\title{
Synthesis and Coordination Chemistry of a Novel Phosphinimine Phosphine
}

\author{
Chung-Yuan Liu, Der-Yi Chen, Ming-Chu Cheng, Shie-Ming Peng, and \\ Shiuh-Tzung Liu* \\ Department of Chemistry, National Taiwan University, Taipei, Taiwan 106, Republic of China
}

Received November $16,1994^{\otimes}$

\begin{abstract}
The incorporation of a phosphinimino moiety into phosphine ligands to form a new bidentate $\mathrm{Ph}_{3} \mathrm{P}=\mathrm{N}\left(\mathrm{CH}_{2}\right)_{3} \mathrm{PPh}_{2}(\mathbf{1})$ is reported. Compound 1 can act as a $\sigma-\mathrm{N}$ and $\sigma-\mathrm{P}$ donor ligand or react with metal carbonyls to form isocyanide complexes. Complexes of $(\mathrm{CO})_{4} \mathrm{M}$ $(1-P, N)[\mathrm{M}=\mathrm{Mo}(2), \mathrm{W}(3)]$ were prepared from the reaction of $\mathrm{Et}_{4} \mathrm{~N}\left[\mathrm{M}(\mathrm{CO})_{5} \mathrm{Br}\right]$ with 1 in refluxing THF solution, whereas the isocyanide complexes of $(\mathrm{CO})_{5} \mathrm{MCN}\left(\mathrm{CH}_{2}\right)_{3} \mathrm{PPh}_{2}[\mathrm{M}=$ $\mathrm{Cr}$ (4), Mo (5), W (6)] are obtained from the reaction of $\mathrm{M}(\mathrm{CO})_{6}$ with 1 at $25{ }^{\circ} \mathrm{C}$. The deoxygenation nature is also shown in the reaction of $\mathrm{CpFe}(\mathrm{CO})_{2} \mathrm{I}, \mathrm{CpRu}(\mathrm{CO})_{2} \mathrm{I}, \operatorname{Re}(\mathrm{CO})_{5} \mathrm{Br}$, and $\operatorname{Re}_{2}(\mathrm{CO})_{10}$ with 1 to form the corresponding isocyanide complexes $\left[\mathrm{CpFe}(\mathrm{CO})\left\{\mathrm{CN}\left(\mathrm{CH}_{2}\right)_{3^{-}}\right.\right.$ $\left.\left.\mathrm{PPh}_{2}-C, P\right\}\right] \mathrm{I}(\mathbf{7}), \mathrm{CpRu}(\mathrm{CO}) \mathrm{I}\left\{\mathrm{CN}\left(\mathrm{CH}_{2}\right)_{3} \mathrm{PPh}_{2}-\mathrm{C}\right\}(\mathbf{1 0}), \mathrm{BrRe}(\mathrm{CO})_{5-n}\left\{\mathrm{CN}\left(\mathrm{CH}_{2}\right)_{3} \mathrm{PPh}_{2}-\mathrm{C}\right\}_{n}[n=$ 1 (12), 2 (14)], and $\operatorname{Re}_{2}(\mathrm{CO})_{9}\left\{\mathrm{CN}\left(\mathrm{CH}_{2}\right)_{3} \mathrm{PPh}_{2}-\mathrm{C}\right\}$ (15), respectively. The free phosphine of 10 underwent exchange with one triphenylphosphine ligand in $\mathrm{CpRu}\left(\mathrm{PPh}_{3}\right)_{2} \mathrm{Cl}$ to yield the binuclear species $\left[\mathrm{CpRu}\left(\mathrm{PPh}_{3}\right) \mathrm{Cl}\left\{\mathrm{P}\left(\mathrm{Ph}_{2}\right)\left(\mathrm{CH}_{2}\right)_{3} \mathrm{NC}\right\} \mathrm{Ru}(\mathrm{CO}) \mathrm{CpI}\right](\mathbf{1 1})$, whereas intramolecular ligand substitution occurred in both 12 and 15 to give $\mathrm{Br}(\mathrm{CO})_{3} \operatorname{Re}\left\{\mathrm{CN}\left(\mathrm{CH}_{2}\right)_{3} \mathrm{PPh}_{2}-\mathrm{C}, P\right\}(\mathbf{1 3})$ and $\left\{\mu-\mathrm{CN}\left(\mathrm{CH}_{2}\right)_{3} \mathrm{PPh}_{2}\right\} \mathrm{Re}_{2}(\mathrm{CO})_{8}(\mathbf{1 6})$. Reaction of $(\mathrm{COD}) \mathrm{PdCl}_{2}$ with 1 produced the complex $(1-P, N) \mathrm{PdCl}_{2}(\mathbf{1 8})$, in which 1 acts as a $\sigma-\mathrm{N}, \sigma$-P bidentate ligand. X-ray crystal structural analysis of $\left[\mathrm{CpFe}(\mathrm{CO})\left\{\mathrm{CN}\left(\mathrm{CH}_{2}\right)_{3} \mathrm{PPh}_{2}-C, P\right\}\right] \mathrm{PF}_{6}(\mathbf{7 a})$ and 18 confirmed the formulation of both complexes. The $\mathrm{C} \equiv \mathrm{N}$ bond distance $[1.20(3) \AA]$ of $\mathbf{7 a}$ is greater than those in the related iron-isocyanide complexes; the angle $\mathrm{C}-\mathrm{N}-\mathrm{C}\left[141(2)^{\circ}\right]$ deviates from $180^{\circ}$, indicating that the resonance contribution of $\mathrm{Fe}=\mathrm{C}=\mathrm{N}$ - is more important than that of $\mathrm{Fe}-\mathrm{C} \equiv \mathrm{N}-$. These observations are consistent with spectral data, the smaller infrared stretching wavenumber $\left(2089 \mathrm{~cm}^{-1}\right)$, and the greater shift $\left({ }^{13} \mathrm{C}\right.$ NMR $\left.\delta 183.7 \mathrm{ppm}\right)$ of the isocyanide moiety of 7 .
\end{abstract}

\section{Introduction}

The nature of the highly polar $\mathrm{P}-\mathrm{N}$ bond in phosphinimine makes a ligand of this kind versatile in both coordination and organometallic chemistry. ${ }^{1-14}$ The nitrogen atom of phosphinimine is able to act as a two-

Abstract published in Advance ACS Abstracts, March 15, 1995.

(1) Dehnicke, K.; Strahle, J. Polyhedron 1989, 8, 707.

(2) Choukroun, R.; Gervais, D.; Dilworth, J. R. Transition Met. Chem. 1979, 4, 249 .

(3) (a) Sleiman, H. F.; Mercer, S.; McElwee-White, L. J. Am. Chem. Soc. 1989, 111, 8007. (b) Briggs, E. M.; Brown, G. W.; Jiricny, J. J Inorg. Nucl. Chem. 1979, 41, 667.

(4) Miller, J. S.; Visscher, M. O.; Caulton, K. G. Inorg. Chem. 1974 13,1632 .

(5) Roesky, H. W.; Munzenberg, J.; Bohra, R.; Noltemeyer, M. J. Organomet. Chem. 1991, 418, 339 .

(6) (a) Alper, H.; Partis, R. A. J. Organomet. Chem. 1972, 35, C40. (b) Mirkin, C. A.; Lu, K.-L.; Geoffroy, G. L. J. Am. Chem. Soc. 1989, 111, 7279. (c) Lin, Y.-W.; Gau, H.-M.; Wen, Y.-S.; Lu, K.-L. Organo. metallics 1992,11,1445.

(7) (a) Maatta, E. A.; Haymore, B. L.; Wentworth, R. A. D. Inorg. Chem. 1980, 19, 1055. (b) Maatta, E. A.; Kim, C. Inorg. Chem. 1989, 28, 623. (c) Chatt, J.; Rowe, G. A. J. Chem. Soc. A 1969, 2288. (d) Chong, A. O.; Oshima, K.; Sharpless, K. B. J. Am. Chem. Soc. 1977, 99,3420 .

(8) Dapporto, P.; Denti, G.; Dolcetti, G.; Ghedini, M. J. Chem. Soc., Dalton Trans. 1983, 779 .

(9) Charalambous, J.; Kensett, M. J.; Jenkins, J. M. J. Chem. Res., Synop. 1982, 306.

(10) Saravanamuthu, A.; Ho, D. M.; Kerr, M. E.; Fitzgerald, C.; Bruce, M. R. M.; Bruce, A. E. Inorg. Chem. 1993, 32, 2202.

(11) Gudat, D.; Niecke, E.; Krebs, B.; Dartmann, M. Organometallics 1986, $5,2376$.

(12) Herring, D. L. J. Org. Chem. 1961, 26, 3998.

(13) Imhoff, P.; van Asselt, R.; Elsevier, C. J.; Zoutberg, M. C.; Stam, C. H. Inorg. Chim. Acta 1991, 184, 73.

0276-7333/95/2314-1983\$09.00/0 electron donor for complexation with various metal ions $\mathrm{s}^{2,3}$ and as a four-electron donor (bridging mode) in $\mathrm{MO}_{2}(\mathrm{CO})_{6}\left(\mathrm{Ph}_{3} \mathrm{PNH}\right)_{3}{ }^{4}$ Furthermore, phosphinimines can react with metal carbonyl complexes ${ }^{6}$ and metal oxides $^{7}$ to produce isocyanide and nitrene functions, respectively, by elimination of phosphine oxide.

Incorporation of a phosphinimino moiety with other donor atoms to form a chelate bidentate has been reported for $9,10-\mathrm{H}_{2} \mathrm{NC}_{14} \mathrm{H}_{8} \mathrm{~N}=\mathrm{PPh}_{3},{ }^{8}$ o-( $\left.\mathrm{HO}\right) \mathrm{C}_{6} \mathrm{H}_{4} \mathrm{~N}=$ $\mathrm{PPh}_{3},{ }^{9}$ 8- $\left(\mathrm{Ph}_{3} \mathrm{P}=\mathrm{N}-\mathrm{C}_{9} \mathrm{H}_{6} \mathrm{~N},{ }^{10}\left(\eta^{1}-\mathrm{C}_{5} \mathrm{Me}_{5}\right) \mathrm{P}=\mathrm{N}(t-\mathrm{Bu}),{ }^{11}\right.$ $\mathrm{Ph}_{3} \mathrm{P}=\mathrm{NC}_{6} \mathrm{H}_{4} \mathrm{~N}=\mathrm{PPh}_{3},{ }^{7 b, 12} \mathrm{Ph}_{2} \mathrm{P}\left(=\mathrm{NR} \mathrm{CH}_{2} \mathrm{PPh}_{2}(=\mathrm{NR}){ }^{13}\right.$ and $\mathrm{PhN}=\mathrm{P}\left(\mathrm{Ph}_{2}\right) \mathrm{CH}=\mathrm{CH}(p-\mathrm{Tol})\left(\mathrm{NH}_{2}\right) .{ }^{14}$ Among these bidentate ligands, only one phosphine-phosphinimine, $\mathrm{Ph}_{2} \mathrm{PCH}_{2} \mathrm{PPh}_{2}\left(=\mathrm{NSiMe}_{3}\right)$, is reported, ${ }^{15}$ for which the coordination mode toward metal ions is confined due to the short carbon chain. We recently showed that the phosphinimine function is stable toward the phosphide nucleophile, which allows us to prepare the potential bidentate phosphino-phosphinimine ligands $1 .^{16}$ Analogous to $\mathrm{Ph}_{2} \mathrm{PCH}_{2} \mathrm{PPh}_{2}\left(=\mathrm{NSiMe}_{3}\right)$, one expects compound 1 to be able to coordinate in a $\sigma-\mathrm{N}$ and $\sigma-\mathrm{P}$ chelate mode toward metal ions and that compound 1 would react

(14) Fernandez, M. J.; Del Val, J. J.; Oro, L. A.; Palacios, F.; Barluenga, J. Polyhedron 1987, 6, 1999.

(15) (a) Katti, K. V.; Cavell, R. G. Organometallics 1988, 7, 2236 (b) Katti, K. V.; Cavell, R. G. Inorg. Chem. 1989, 28, 413. (c) Katti, K. V.; Cavell, R. G. Inorg. Chem. 1989, 28, 3033. (d) Katti, K. V.; Cavell, R. G. Organometallics $\mathbf{1 9 8 9}, 8,2147$. (e) Katti, K. V.; Batchelor, R. J.; Einstein, F. W. B.; Cavell, R. G. Inorg, Chem. 1990, 29, 808. (f) Katti, K. V.; Cavell, R. G. Organometallics 1991, 10, 539 .

(16) Liu, S.-T.; Liu, C.-Y. J. Org. Chem. 1992, 57, 6079. 

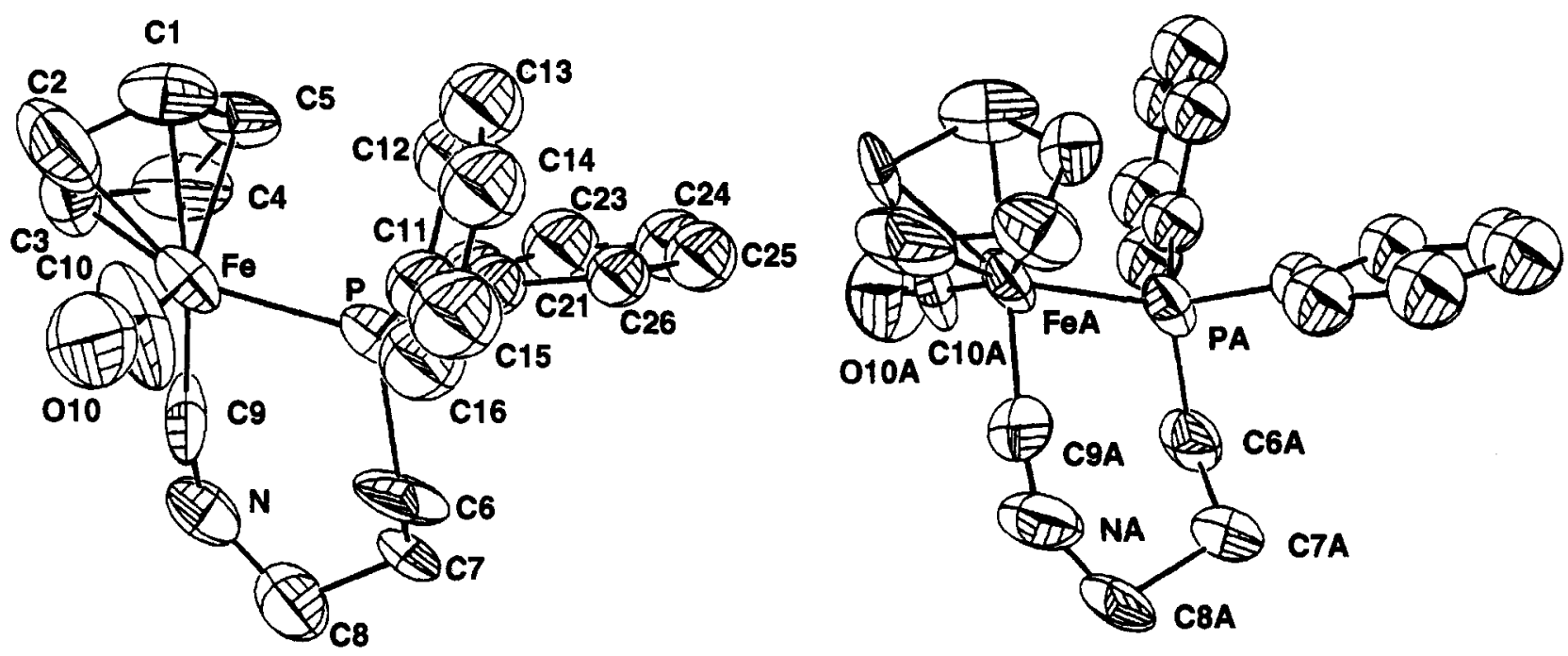

Figure 1. ORTEP view of the cation of complex $\mathbf{7 a}$ showing $50 \%$ probability thermal ellipsoids. Two indepent molecules exist in the unit cell.
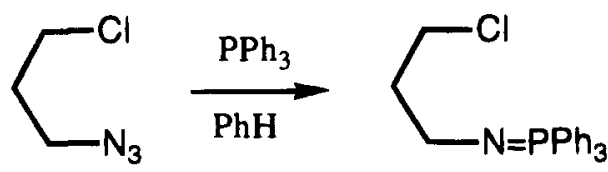

with a metal-carbonyl ligand to form a new ligand $\mathrm{CN}$ $\left(\mathrm{CH}_{2}\right)_{3} \mathrm{PPh}_{2}$ of bidenate type in either a bridging or a chelating mode. Here we report the results of coordination chemistry of 1 toward various metal complexes.

$$
\mathrm{Ph}_{3} \mathrm{P}=\mathrm{N}-\left(\mathrm{CH}_{2}\right)_{3}-\mathrm{PPh}_{2}
$$

\section{Results and Discussion}

The ligand $\mathrm{Ph}_{3} \mathrm{P}=\mathrm{N}\left(\mathrm{CH}_{2}\right)_{3} \mathrm{PPh}_{2}$ was obtained after isolation of the intermediate in the synthesis of $\mathrm{H}_{2} \mathrm{~N}$ $\left(\mathrm{CH}_{2}\right)_{3} \mathrm{PPh}_{2}$ (Scheme 1). ${ }^{16}$ This phosphino-phosphinimine 1 is stable in air but sensitive to moisture. The ${ }^{31} \mathrm{P}$ NMR spectrum of the new ligand displays two singlets at -16.0 and $4.3 \mathrm{ppm}$ in benzene- $d_{6}$ for diphenylphosphino and iminophosphorane moieties, respectively. The ${ }^{31} \mathrm{P}$ chemical shift corresponding to the moiety of $\mathrm{Ph}_{3} \mathrm{P}=\mathrm{N}$ - is varied from nonpolar solvent to polar solvent. Thus the chemical shift of the phosphinimino moiety is $12.1 \mathrm{ppm}$ in $\mathrm{CDCl}_{3}$, indicating the polar nature of the $\mathrm{P}-\mathrm{N}$ bond.

Addition of 1 to a stirred tetrahydrofuran solution of $\mathrm{NEt}_{4}\left[\mathrm{M}(\mathrm{CO})_{5} \mathrm{Br}\right](\mathrm{M}=\mathrm{Mo}, \mathrm{W})$ at refluxing temperature results in the formation of chelate complexes $(\mathrm{CO})_{4} \mathrm{M}$ $(1-P, N)[2, \mathrm{M}=\mathrm{Mo} ; 3, \mathrm{M}=\mathrm{W}]$. Both complexes were isolated as solids stable in air and characterized by spectral methods. The carbonyl stretching wavenumbers of the complexes occur in the $2010-1900 \mathrm{~cm}^{-1}$ region, which is in accord with a tetracarbonyl species. The ${ }^{31} \mathrm{P}$ NMR spectrum displays two sets of doublets [39.4 (d, $J=14 \mathrm{~Hz}), 16.3(\mathrm{~d}, J=14 \mathrm{~Hz}) \mathrm{ppm}$ for 2 and $37.9(\mathrm{~d}, J=18 \mathrm{~Hz}), 2.67\left(\mathrm{dt}, J_{\mathrm{P}-\mathrm{P}}=18 \mathrm{~Hz}, J_{\mathrm{P}-\mathrm{W}}=224\right.$ $\mathrm{Hz}$ ) ppm for 3 ] due to phosphorus atoms of two kinds coupled to each other. Both the coordination chemical shifts and long range phosphorus-phosphorus couplings verify the existence of the $\mathrm{Ph}_{3} \mathrm{P}=\mathrm{N}$ - moiety in the complexes. The infrared spectra of both $\mathbf{2}$ and $\mathbf{3}$ exhibit

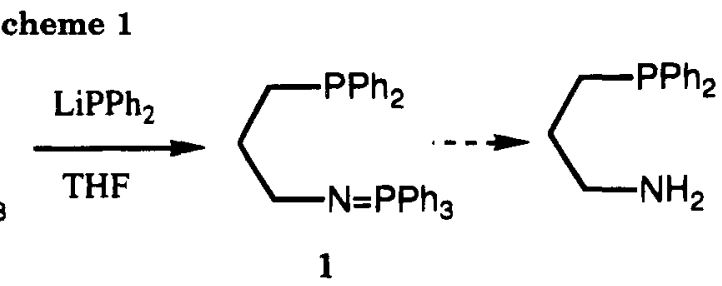

Table 1. Infrared Absorptions and ${ }^{13} \mathrm{C}$ NMR Chemical Shifts of Isocyanide Complexes ${ }^{a}$

\begin{tabular}{|c|c|c|c|}
\hline complex & $\nu_{\mathrm{CN}}, \mathrm{cm}^{-1}$ & $\begin{array}{c}{ }^{13} \mathrm{C} \text { NMR, } \\
\text { ppm }\end{array}$ & ref \\
\hline 4 & 2173 & 162.5 & this work \\
\hline 5 & 2173 & 153.4 & this work \\
\hline 6 & 2175 & 143.0 & this work \\
\hline 7 & 2089 & $\begin{array}{r}183.7(\mathrm{~d}, \\
J_{\mathrm{P}-\mathrm{C}}= \\
35 \mathrm{~Hz})\end{array}$ & this work \\
\hline$\left[\mathrm{CpFe}\left(\mathrm{PPh}_{3}\right)(\mathrm{CO})\left(\mathrm{CNCH}_{3}\right)\right] \mathrm{BF}_{4}$ & 2194 & & 20 \\
\hline 10 & 2170 & 145.1 & this work \\
\hline 11 & 2170 & $144.9,144.8^{c}$ & this work \\
\hline 12 & 2222 & 129.2 & this work \\
\hline $\operatorname{ReBr}(\mathrm{CO})_{4}(\mathrm{CNPr})$ & 2221 & 129.4 & 21 \\
\hline 13 & 2138 & $\begin{array}{r}163(\mathrm{~d} \\
J_{\mathrm{P}-\mathrm{C}}= \\
6.8 \mathrm{~Hz})\end{array}$ & this work \\
\hline $\mathrm{fac}^{\prime} \mathrm{Re}(\mathrm{CO})_{3}\left(\mathrm{CN}^{\prime} \mathrm{Bu}\right)\left(\mathrm{PPh}_{2} \mathrm{Me}\right) \mathrm{Br}$ & 2186 & & 23 \\
\hline $\mathrm{fac}^{\prime}-\mathrm{Re}(\mathrm{CO})_{3}\left(\mathrm{CN}^{\prime} \mathrm{Bu}\right)\left(\mathrm{PPh}_{3}\right) \mathrm{Br}$ & 2181 & & 23 \\
\hline 14 & 2219,2192 & 134.3 & this work \\
\hline $\operatorname{ReBr}(\mathrm{CO})_{3}(\mathrm{CNPr})_{2}$ & 2219,2197 & 134.5 & 21 \\
\hline 15 & 2187 & 134.5 & this work \\
\hline $\operatorname{Re}_{2}(\mathrm{CO})_{9}\left(\mathrm{CN}^{\prime} \mathrm{Bu}\right)$ & $2173^{d t}$ & & 22 \\
\hline 16 & $2156^{b}$ & 178.9 & this work \\
\hline 17 & 2221 & 130.7 & this work \\
\hline
\end{tabular}

" Recored in $\mathrm{CH}_{2} \mathrm{Cl}_{2}$ for IR and in $\mathrm{CDCl}_{3}$ for ${ }^{13} \mathrm{C}$ NMR, unless otherwise noted. " $\mathrm{KBr}$. "Diastereomers. "In hexane.

no band that could be assigned to $\mathrm{C} \equiv \mathrm{N}$ - modes, in agreement with the structural formulation. Apparently, compound 1 acts as a simple chelate ligand (a $\sigma-\mathrm{N}$ and $\sigma-\mathrm{P}$ chelate mode) in $\mathrm{Mo}(0)$ and $\mathrm{W}(0)$ complexes.

Deoxygenation of the carbonyl group took place in the reaction of 1 with $\mathrm{M}(\mathrm{CO})_{6}$ at room temperature to yield the corresponding isocyanide complex $(\mathrm{CO})_{5} \mathrm{M}\left[\mathrm{CN}\left(\mathrm{CH}_{2}\right)_{3^{-}}\right.$ $\left.\mathrm{PPh}_{2}-\mathrm{C}\right)[4, \mathrm{M}=\mathrm{Cr} ; 5, \mathrm{M}=\mathrm{Mo} ; 6, \mathrm{M}=\mathrm{W}]$. The structural determination of 4-6 was confirmed by infrared and NMR spectra. Infrared spectra of these series complexes exhibit characteristic absorptions at ca. $2174 \mathrm{~cm}^{-1}$ for the coordinated isocyanide group and 
Table 2. Atomic Parameters and Thermal Parameters of $7 \mathbf{a}$

\begin{tabular}{|c|c|c|c|c|}
\hline & $x$ & $y$ & $z$ & $B_{\mathrm{eq}}, \AA^{2}$ \\
\hline $\mathrm{Fe}$ & $0.8039(4)$ & $0.10504(21)$ & $0.315 l(3)$ & $4.74(20)$ \\
\hline $\mathrm{FeA}$ & $-0.2101(4)$ & $0.60450(21)$ & $0.1790(3)$ & $4.93(21)$ \\
\hline $\mathrm{P}$ & $0.9299(8)$ & $0.0482(4)$ & $0.2060(5)$ & $4.5(4)$ \\
\hline PA & $-0.0815(8)$ & $0.5491(4)$ & $0.2933(5)$ & $4.5(4)$ \\
\hline $\mathrm{Cl}$ & $0.693(3)$ & $0.0222(15)$ & $0.3925(16)$ & $5.8(15)$ \\
\hline $\mathrm{C} 2$ & $0.644(3)$ & $0.0930(17)$ & $0.4132(22)$ & $9.4(22)$ \\
\hline $\mathrm{C} 3$ & $0.764(3)$ & $0.1324(15)$ & $0.4491(18)$ & $6.3(16)$ \\
\hline $\mathrm{C} 4$ & $0.891(3)$ & $0.0897(16)$ & $0.4446(17)$ & $6.7(16)$ \\
\hline C5 & $0.8376(25)$ & $0.0201(14)$ & $0.4105(15)$ & $5.0(14)$ \\
\hline C6 & $1.000(3)$ & $0.1108(13)$ & $0.1170(16)$ & $6.4(17)$ \\
\hline $\mathrm{C} 7$ & $1.138(3)$ & $0.1578(13)$ & $0.1465(18)$ & $7.1(17)$ \\
\hline $\mathrm{C} 8$ & $1.106(3)$ & $0.2374(15)$ & $0.1836(18)$ & $6.6(18)$ \\
\hline $\mathrm{N}$ & $0.9989(22)$ & $0.2295(10)$ & $0.2562(13)$ & $5.6(12)$ \\
\hline $\mathrm{C} 9$ & $0.9133(25)$ & $0.1844(14)$ & $0.2854(18)$ & $5.6(15)$ \\
\hline $\mathrm{C} 10$ & $0.668(3)$ & $0.1222(15)$ & $0.2373(23)$ & $9.4(21)$ \\
\hline $\mathrm{O} 10$ & $0.5616(20)$ & $0.1276(12)$ & $0.1930(13)$ & $9.1(13)$ \\
\hline $\mathrm{Cll}$ & $0.818(3)$ & $-0.0158(14)$ & $0.1395(15)$ & $4.9(6)$ \\
\hline $\mathrm{C} 12$ & $0.778(3)$ & $-0.0877(15)$ & $0.1793(16)$ & $5.7(7)$ \\
\hline $\mathrm{C} 13$ & $0.678(3)$ & $-0.1348(15)$ & $0.1320(16)$ & $5.9(7)$ \\
\hline $\mathrm{C} 14$ & $0.622(3)$ & $-0.1131(15)$ & $0.0470(16)$ & $5.9(7)$ \\
\hline $\mathrm{C} 15$ & $0.659(3)$ & $-0.0480(16)$ & $0.0074(18)$ & $6.9(8)$ \\
\hline $\mathrm{C} 16$ & $0.753(3)$ & $0.0006(15)$ & $0.0554(17)$ & $6.4(7)$ \\
\hline $\mathrm{C} 2 \mathrm{I}$ & $1.0888(24)$ & $-0.0072(13)$ & $0.2416(14)$ & $4.1(6)$ \\
\hline $\mathrm{C} 22$ & $1.176(3)$ & $0.0137(14)$ & $0.3150(16)$ & $5.5(7)$ \\
\hline $\mathrm{C} 23$ & $1.301(3)$ & $-0.0266(15)$ & $0.3377(17)$ & $6.5(7)$ \\
\hline $\mathrm{C} 24$ & $1.346(3)$ & $-0.0803(15)$ & $0.2771(16)$ & $5.9(7)$ \\
\hline $\mathrm{C} 25$ & $1.265(3)$ & $-0.1006(14)$ & $0.2047(15)$ & $5.3(7)$ \\
\hline $\mathrm{C} 26$ & $1.1355(24)$ & $-0.0681(13)$ & $0.1824(14)$ & $3.9(6)$ \\
\hline $\mathrm{ClA}$ & $-0.109(3)$ & $0.5891(15)$ & $0.0512(17)$ & $6.6(16)$ \\
\hline $\mathrm{C} 2 \mathrm{~A}$ & $-0.246(4)$ & $0.6364(15)$ & $0.0397(19)$ & $8.5(20)$ \\
\hline $\mathrm{C} 3 \mathrm{~A}$ & $-0.364(3)$ & $0.5954(15)$ & $0.0664(19)$ & $7.5(17)$ \\
\hline $\mathrm{C} 4 \mathrm{~A}$ & $-0.307(3)$ & $0.5193(15)$ & $0.0988(16)$ & $6.5(16)$ \\
\hline C5A & $-0.162(3)$ & $0.5223(14)$ & $0.0827(14)$ & $4.5(14)$ \\
\hline $\mathrm{C} 6 \mathrm{~A}$ & $-0.009(3)$ & $0.6139(14)$ & $0.3840(16)$ & $5.3(15)$ \\
\hline C7A & $0.124(3)$ & $0.6643(14)$ & $0.3626(18)$ & $6.1(16)$ \\
\hline $\mathrm{C} 8 \mathrm{~A}$ & $0.074(3)$ & $0.7477(14)$ & $0.3228(19)$ & $6.9(18)$ \\
\hline NA & $-0.029(3)$ & $0.7323(11)$ & $0.2462(13)$ & $7.1(14)$ \\
\hline $\mathrm{C} 9 \mathrm{~A}$ & $-0.104(3)$ & $0.6870(14)$ & $0.2157(16)$ & $6.3(16)$ \\
\hline $\mathrm{C} 10 \mathrm{~A}$ & $-0.350(3)$ & $0.6229(14)$ & $0.2482(17)$ & $5.2(14)$ \\
\hline O10A & $-0.4500(20)$ & $0.6329(12)$ & $0.2949(12)$ & $8.7(13)$ \\
\hline C11A & $-0.1901(25)$ & $0.4821(13)$ & $0.3532(15)$ & $4.6(6)$ \\
\hline $\mathrm{C} 12 \mathrm{~A}$ & $-0.252(3)$ & $0.4972(15)$ & $0.4341(16)$ & $5.6(7)$ \\
\hline C13A & $-0.344(3)$ & $0.4453(17)$ & $0.4784(19)$ & $8.1(8)$ \\
\hline $\mathrm{Cl} 4 \mathrm{~A}$ & $-0.369(3)$ & $0.3783(16)$ & $0.4340(18)$ & $7.1(8)$ \\
\hline $\mathrm{C} 15 \mathrm{~A}$ & $-0.319(3)$ & $0.3588(16)$ & $0.3554(18)$ & $7.6(8)$ \\
\hline $\mathrm{C} 16 \mathrm{~A}$ & $-0.222(3)$ & $0.4086(14)$ & $0.3099(16)$ & $5.6(7)$ \\
\hline $\mathrm{C} 21 \mathrm{~A}$ & $0.0803(24)$ & $0.4988(13)$ & $0.2652(14)$ & $3.9(6)$ \\
\hline $\mathrm{C} 22 \mathrm{~A}$ & $0.129(3)$ & $0.4378(15)$ & $0.3219(16)$ & $5.7(7)$ \\
\hline $\mathrm{C} 23 \mathrm{~A}$ & $0.268(3)$ & $0.4053(15)$ & $0.3038(16)$ & $5.8(7)$ \\
\hline $\mathrm{C} 24 \mathrm{~A}$ & $0.344(3)$ & $0.4237(16)$ & $0.2312(17)$ & $6.6(7)$ \\
\hline $\mathrm{C} 25 \mathrm{~A}$ & $0.297(3)$ & $0.4861(16)$ & $0.1718(17)$ & $6.7(7)$ \\
\hline $\mathrm{C} 26 \mathrm{~A}$ & $0.165(3)$ & $0.5195(15)$ & $0.1943(16)$ & $5.5(7)$ \\
\hline P1 & $0.2762(10)$ & $0.7122(5)$ & $-0.0048(6)$ & $7.3(5)$ \\
\hline $\mathrm{Fl}$ & $0.373(3)$ & $0.7305(10)$ & $0.0772(15)$ & $15.7(16)$ \\
\hline $\mathrm{F} 2$ & $0.189(3)$ & $0.6917(14)$ & $-0.0872(16)$ & $19.2(20)$ \\
\hline F3 & $0.2680(23)$ & $0.6285(9)$ & $0.0263(13)$ & $12.4(14)$ \\
\hline $\mathrm{F} 4$ & $0.2832(24)$ & $0.7966(12)$ & $-0.0284(18)$ & $18.1(20)$ \\
\hline F5 & $0.1334(22)$ & $0.7286(12)$ & $0.0395(17)$ & $15.5(17)$ \\
\hline F6 & $0.4217(23)$ & $0.6960(13)$ & $-0.0516(14)$ & $15.4(16)$ \\
\hline $\mathrm{P} 2$ & $0.6984(10)$ & $0.7900(5)$ & $0.4896(6)$ & $7.0(5)$ \\
\hline F7 & $0.643(3)$ & $0.7798(10)$ & $0.5868(12)$ & $13.4(15)$ \\
\hline F8 & $0.752(3)$ & $0.8018(12)$ & $0.3930(12)$ & $15.2(16)$ \\
\hline FY & $0.703(3)$ & $0.8747(9)$ & $0.5146(15)$ & $14.8(16)$ \\
\hline $\mathrm{F} 10$ & $0.6975(23)$ & $0.7042(10)$ & $0.4713(15)$ & $13.5(15)$ \\
\hline F11 & $0.8552(20)$ & $0.7828(12)$ & $0.5213(15)$ & $14.3(16)$ \\
\hline $\mathrm{F} 12$ & $0.5378(21)$ & $0.7955(12)$ & $0.4558(13)$ & $13.4(14)$ \\
\hline
\end{tabular}

at ca. 2070 and $1955 \mathrm{~cm}^{-1}$ for the pentacarbonylmetal moiety. The ${ }^{13} \mathrm{C}$ NMR shifts of the isocyanide carbon appear at $162.5 \mathrm{ppm}$ for $4,153.4 \mathrm{ppm}$ for 5 , and 143.0 ppm for 6, respectively. Both IR and NMR data indicate the existence of an isocyanide function. The formation of isocyanide complex is presumably proceeded by the nucleophilic attack of iminophosphorane at the carbonyl ligand followed by the elimination of triphenylphosphine
Table 3. Selected Bond Distances $(\AA)$ and Bond Angles (deg)

\begin{tabular}{|c|c|c|c|}
\hline \multicolumn{4}{|c|}{ Complex 7a } \\
\hline $\mathrm{Fe}-\mathrm{P}$ & $2.229(9)$ & $\mathrm{FeA}-\mathrm{PA}$ & $2.229(9)$ \\
\hline $\mathrm{Fe}-\mathrm{C} 9$ & $1.77(2)$ & $\mathrm{FeA}-\mathrm{C} 9 \mathrm{~A}$ & $1.80(2)$ \\
\hline $\mathrm{Fe}-\mathrm{ClO}$ & $1.67(3)$ & $\mathrm{FeA}-\mathrm{C} 10 \mathrm{~A}$ & $1.69(2)$ \\
\hline $\mathrm{C} 9-\mathrm{N}$ & $1.20(3)$ & $\mathrm{C} 9 \mathrm{~A}-\mathrm{NA}$ & $1.12(3)$ \\
\hline $\mathrm{N}-\mathrm{C} 8$ & $1.47(3)$ & $\mathrm{NA}-\mathrm{C} 8 \mathrm{~A}$ & $1.45(3)$ \\
\hline $\mathrm{ClO}-\mathrm{O} 10$ & $1.16(3)$ & $\mathrm{C} 10 \mathrm{~A}-\mathrm{O} 10 \mathrm{~A}$ & $1.17(3)$ \\
\hline $\mathrm{Cl} 0-\mathrm{Fe}-\mathrm{P}$ & $90(1)$ & $\mathrm{ClOA}-\mathrm{FeA}-\mathrm{PA}$ & $92.2(8)$ \\
\hline $\mathrm{Cl} 0-\mathrm{Fe}-\mathrm{C} 9$ & $96(1)$ & $\mathrm{C} 10 \mathrm{~A}-\mathrm{Fe} A-\mathrm{C} 9 \mathrm{~A}$ & $95(1)$ \\
\hline $\mathrm{C} 9-\mathrm{Fe}-\mathrm{P}$ & $82.0(8)$ & $\mathrm{C} 9 \mathrm{~A}-\mathrm{FeA}-\mathrm{PA}$ & $82.7(8)$ \\
\hline $\mathrm{Fe}-\mathrm{C} 9-\mathrm{N}$ & $169(2)$ & $\mathrm{FeA}-\mathrm{C} 9 \mathrm{~A}-\mathrm{NA}$ & $171(2)$ \\
\hline $\mathrm{C} 9-\mathrm{N}-\mathrm{C} 8$ & $141(2)$ & $\mathrm{C} 9 \mathrm{~A}-\mathrm{NA}-\mathrm{C} 8 \mathrm{~A}$ & $142(2)$ \\
\hline $\mathrm{Fe}-\mathrm{ClO}-\mathrm{O} 10$ & $169(3)$ & $\mathrm{FeA}-\mathrm{C} 10 \mathrm{~A}-\mathrm{O} 10 \mathrm{~A}$ & $177(2)$ \\
\hline \multicolumn{4}{|c|}{ Complex 18} \\
\hline $\mathrm{Pd}-\mathrm{Cll}$ & $2.371(2)$ & $\mathrm{Pd}-\mathrm{N}$ & $2.067(5)$ \\
\hline $\mathrm{Pd}-\mathrm{Cl} 2$ & $2.277(2)$ & $\mathrm{P} 2-\mathrm{N}$ & $1.575(6)$ \\
\hline $\mathrm{Pd}-\mathrm{Pl}$ & $2.203(2)$ & & \\
\hline $\mathrm{Cl} 1-\mathrm{Pd}-\mathrm{Cl} 2$ & $91.17(8)$ & $\mathrm{Pl}-\mathrm{Pd}-\mathrm{N}$ & $83.5(2)$ \\
\hline $\mathrm{Cl} 2-\mathrm{Pd}-\mathrm{Pl}$ & $92.19(8)$ & $\mathrm{P} 2-\mathrm{N}-\mathrm{C} 8$ & $119.4(4)$ \\
\hline $\mathrm{Cl} 2-\mathrm{Pd}-\mathrm{N}$ & $175.1(2)$ & $\mathrm{P} 2-\mathrm{N}-\mathrm{Pd}$ & $125.6(3)$ \\
\hline $\mathrm{Cll}-\mathrm{Pd}-\mathrm{Pl}$ & $171.17(8)$ & $\mathrm{C} 8-\mathrm{N}-\mathrm{Pd}$ & $112.8(4)$ \\
\hline $\mathrm{Cl} 1-\mathrm{Pd}-\mathrm{N}$ & $93.4(2)$ & & \\
\hline
\end{tabular}

oxide. $^{6}$ It appears that the carbonyl ligand of $\mathrm{M}(\mathrm{CO})_{6}$ is more reactive toward nucleophilic attack by the iminophosphorane than that of $\left[\mathrm{M}(\mathrm{CO})_{5} \mathrm{Br}\right]^{-}$. Such a difference is believed due to the poorer $\mathrm{M}-\mathrm{C}$ backbonding of $\mathrm{M}(\mathrm{CO})_{6}$ compared with that of $\left[\mathrm{M}(\mathrm{CO})_{5} \mathrm{Br}\right]^{-}$.

Reaction of phosphine-phosphinimine 1 with $\mathrm{CpFe}$ $(\mathrm{CO})_{2} \mathrm{I}\left[\mathrm{Cp}=\eta^{5}-\mathrm{C}_{5} \mathrm{H}_{5}\right]$ in toluene at $25{ }^{\circ} \mathrm{C}$ yielded a yellow precipitate $\left\{\mathrm{CpFe}(\mathrm{CO})\left[\mathrm{CNCH}_{2} \mathrm{CH}_{2} \mathrm{CH}_{2} \mathrm{PPh}_{2-}\right.\right.$ $P, C]\} I$ (7) and triphenylphosphine oxide; the desired complex was purified by extraction of $\mathrm{Ph}_{3} \mathrm{P}=\mathrm{O}$ with toluene from the reaction mixture. Anionic metathesis of 7 with $\mathrm{NH}_{4} \mathrm{PF}_{6}$ gave $\left\{\mathrm{CpFe}(\mathrm{CO})\left[\mathrm{CNCH}_{2} \mathrm{CH}_{2} \mathrm{CH}_{2}\right.\right.$ $\left.\left.\mathrm{PPh}_{2}-P, C\right]\right\} \mathrm{PF}_{6}(\mathbf{7 a})$ as a crystalline solid upon recrystallization. The phosphinimine function of 1 acts as a deoxygenating agent, which reacts with the carbonyl ligand to form an isocyanide moiety. In the infrared spectrum of 7 , the stretching wavenumbers corresponding to isocyanide $\left(2089 \mathrm{~cm}^{-1}\right)$ and carbonyl $\left(1998 \mathrm{~cm}^{-1}\right)$ were observed, clearly indicating the existence of both moieties around the metal center. An ORTEP plot of the cation of $7 \mathbf{a}$ is illustrated in Figure 1. Atomic coordinates and selected bond distances and angles are listed in Tables 2 and 3, respectively. The iron atom displays a slightly distorted octahedral geometry with one face occupied by the cyclopentadienyl moiety. The $\mathrm{Fe}-\mathrm{C} 9$ distance $[1.77(2) \AA]$ is smaller and the $\mathrm{C} 9-\mathrm{N}$ distance $[1.20(3) \AA]$ is larger than the average bond distance of $\mathrm{Fe}-\mathrm{C}(1.84 \AA)$ and $\mathrm{C}-\mathrm{N}(1.17 \AA)$ in complexes of $\mathrm{Fe}(t-\mathrm{BuNC})_{5},{ }^{17} \mathrm{Fe}\left(\mathrm{C}_{6} \mathrm{H}_{8}\right)(\mathrm{CO})_{2}(\mathrm{EtNC}),{ }^{18}$ and $\mathrm{Fe}_{2}(\mathrm{EtNC})_{9},{ }^{19}$ respectively. The angle $\mathrm{C} 9-\mathrm{N}-\mathrm{C} 8$ [141$\left.(2)^{\circ}\right]$ is much deviated from $180^{\circ}$. All this information indicates that the nitrogen atom is no longer restrained in a linear environment, which implies that the reso-

(17) Bassett, J.-M.; Berry, D. E.; Barker, G. K.; Green, M.; Howard, J. A. K.; Stone, F. G. A. J. Chem. Soc., Dalton Trans. 1979, 1003.

(18) Yamamoto, Y. Coord. Chem. Rev. 1980, 32, 193.

(19) Bassett, J.-M.; Barker, G. K.; Green, M.; Howard, J. A. K.; Stone, F. G. A.; Wolsey, W. C. J. Chem. Soc., Dalton Trans. 1981, 219. (20) Angelici, R. J.; Christian, P. A.; Dombek, B. D.; Pfeffer, G. A. $J$. Organomet. Chem. 1974, 67, 287.

(21) Chen, L.-C.; Chen, M.-Y.; Chen, J.-H.; Wen, Y.-S.; Lu, K.-L. J. Organomet. Chem. 1992, $425,99$.

(22) Harris, G. W.; Coville, N. J. Organometallics 1985, 4, 908.

(23) Leins, A. E.; Coville, N. J. J. Organomet. Chem. 1994, 464, 183. 


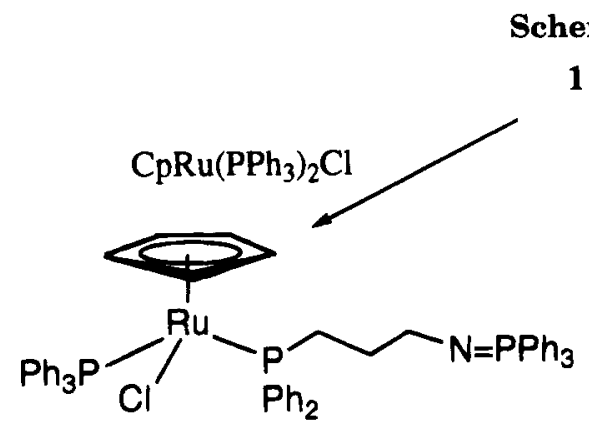

9

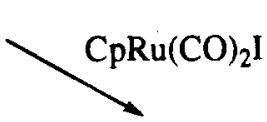

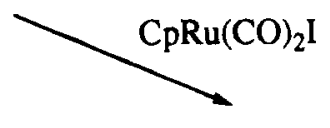

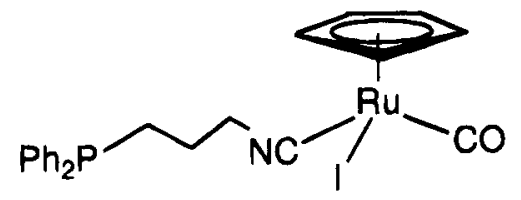

10

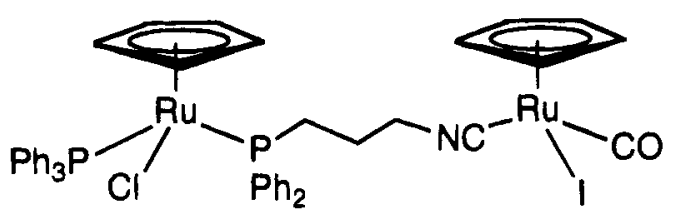

11

nance form $\mathrm{Fe}=\mathrm{C}=\mathrm{N}-$ in the coordinated isocyanide group is much more important than $\mathrm{Fe}-\mathrm{C} \equiv \mathrm{N}-$. This observation is also consistent with the smaller stretching wavenumber of isocyanide $\left(2089 \mathrm{~cm}^{-1}\right)$ in 7 (Table 1) compared with $\left[\mathrm{CpFe}\left(\mathrm{PPh}_{3}\right)(\mathrm{CO})\left(\mathrm{CNCH}_{3}\right)\right] \mathrm{BF}_{4}(2194$ $\mathrm{cm}^{-1}$ ). Complex 7 readily reacted with propylamine to give carbene complex 8 . The structure of this carbene metal complex was determined by spectral and elemental analyses (Experimental Section).

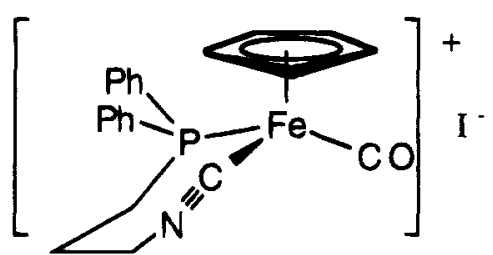

7

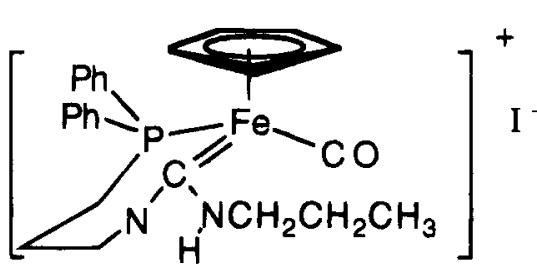

8

The chemistry of 1 toward ruthenium(II) complexes is summarized in Scheme 2. As expected, the ligand substitution reaction of $\mathrm{CpRu}\left(\mathrm{PPh}_{3}\right)_{2} \mathrm{Cl}$ by the phosphino site of $\mathbf{1}$ took place immediately to yield the simple substituted complex $\mathbf{9}$, but further substitution to form a $\sigma-\mathrm{N}$ and $\sigma-\mathrm{P}$ chelate complex did not occur, even under severe reaction conditions. Reaction of 1 with $\mathrm{CpRu}$ $(\mathrm{CO})_{2} \mathrm{I}$ produced isocyanide complex 10 accompanied by formation of triphenylphosphine oxide. Unlike the iron complex, the diphenylalkylphosphine moiety in $\mathbf{1 0}$ remained as a free donor. Attempts to prepare a chelating mode of $\mathrm{CN}\left(\mathrm{CH}_{2}\right)_{3} \mathrm{PPh}_{2}$ complex, like the iron analog, failed. Nevertheless, the uncoordinating donors in both 9 and 10 become an advantage in preparation of a binuclear species. Thus reaction of either complex 9 with $\mathrm{CpRu}(\mathrm{CO})_{2} \mathrm{I}$ or complex 10 with $\mathrm{CpRu}\left(\mathrm{PPh}_{3}\right)_{2} \mathrm{Cl}$ yielded a bridging diruthenium complex 11. As both ruthenium centers are chiral, the diastereomeric pair of complexes 11 were observed in ${ }^{31} \mathrm{P}$ NMR spectrum: one is 44.1 and $35.7 \mathrm{ppm}$; the other is 44.0 and $35.8 \mathrm{ppm}$. All these absorptions appear as doublets with phosphorus-phosphorus coupling constant $41 \mathrm{~Hz}$. Attempts to separate these isomers by chromatography and recrystallization were unsuccessful.

The ruthenium complexes were characterized by spectral and elemental analyses. The ${ }^{31} \mathrm{P}$ NMR spectrum of complex 9 shows three sets of resonances: 44.1 (d, $\left.J=41 \mathrm{~Hz}, \mathrm{PPh}_{3}\right) ; 36.8\left(\mathrm{~d}, J=41 \mathrm{~Hz},-\mathrm{PPh}_{2}\right.$ ), and $13.0\left(\mathrm{br},-\mathrm{N}=\mathrm{PPh}_{3}\right) \mathrm{ppm}$, in which the broad peak at $13.0 \mathrm{ppm}$ corresponds to the free phosphinimine site. The naturally abundant ratio of ${ }^{35} \mathrm{Cl}$ and ${ }^{37} \mathrm{Cl}$ in the $\mathrm{FAB}$ mass spectrum of 9 indicates that the chloride is a coordinated ligand around the metal ion. The ${ }^{31} \mathrm{P}$ NMR spectrum of complex 10 shows only a signal due to a free diphenylalkylphosphine at $\delta-17.3 \mathrm{ppm}$, thus indicating that the phosphine moiety did not coordinate to the metal center and the phosphinimine function disappeared. Both infrared and ${ }^{13} \mathrm{C}$ NMR spectra of 10 show the presence of a coordinated isocyanide (2107 $\mathrm{cm}^{-1}$ ) and a carbonyl ligand [IR $2107 \mathrm{~cm}^{-1}(\mathrm{NC})$ and $1973 \mathrm{~cm}^{-1}(\mathrm{CO}) ;{ }^{13} \mathrm{C}$ NMR $\delta 145.1 \mathrm{ppm}(\mathrm{CN})$ and 199.5 ppm (CO)]. On this basis with elemental analysis the ruthenium complexes 10 and 11 were assigned as formulated.

When $\operatorname{Re}(\mathrm{CO})_{5} \mathrm{Br}$ reacted with 1 under thermal conditions, deoxygenation at the carbonyl ligand occurred in dichloromethane solution to form an isocyanide complex 12. The phosphine site of 1 in complex 12 remained a free donor, but it underwent further substitution with carbonyl ligands to give 13. Treatment of 12 with 1 in a further equimolar quantity provided the diisocyanide 


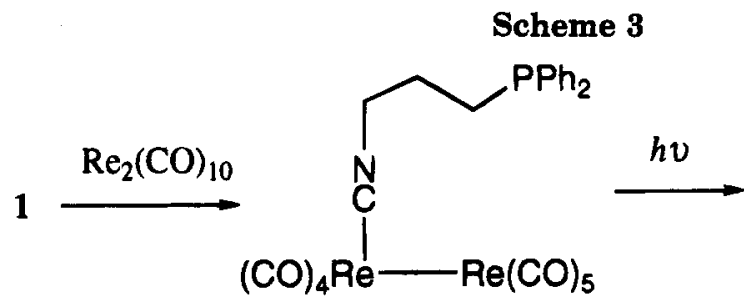

15

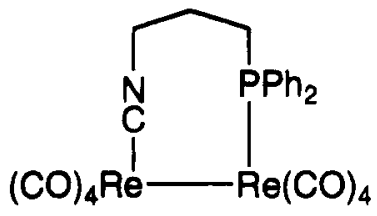

16

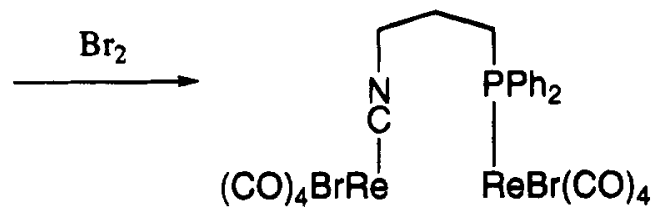

17

species 14 that has two free phosphine donors away from the metal center. The structures of 12-14 were confirmed by their spectral properties (see Experimental Section). The infrared stretching wavenumber of the isocyanide moiety $\left(2138 \mathrm{~cm}^{-1}\right)$ in 13 is smaller than that of the other $\mathrm{Re}-\mathrm{CN}$ species and the ${ }^{13} \mathrm{C}$ NMR shift of isocyanide carbon ( $\delta 163 \mathrm{ppm}$ ) is also greater than those of related species (Table 1), similar to complex 7 due to ring strain.

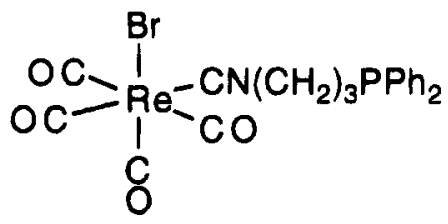

12<smiles></smiles>

13

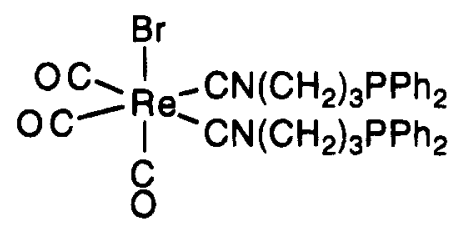

14

Reaction of phosphino-phosphinimine 1 with dirhenium decacarbonyl also yielded isocyanide complex $\mathbf{1 5}$ in which the phosphino site stays uncoordinated. On irradiation of 15 in chloroform with light, the phosphine exchanged a carbonyl ligand to form a bridging binuclear complex 16 (Scheme 3). Because of the ring strain of 16, the properties of the coordinated isocyanide ligand in both infrared and ${ }^{13} \mathrm{C}$ NMR spectra show the same trend as in complexes 7 and 13: a smaller wavenumber of the infrared stretching mode of $\mathrm{CN}-$ and a considerable downfield chemical shift of ${ }^{13} \mathrm{C}$ NMR of $\mathrm{CN}-$. The lack of phosphorus-carbon coupling of the isocyanide carbon supports assignment of a structure in which $\mathrm{CN}\left(\mathrm{CH}_{2}\right)_{3} \mathrm{PPh}_{2}$ binds in a bridging mode, not a chelating one. Upon treatment of $\mathbf{1 6}$ with bromine, the cleavage of the metal-metal bond of 16 occurred to yield $\mathrm{Br}(\mathrm{CO})_{4} \operatorname{Re}\left\{\mu_{2}-\left(\mathrm{CNCH}_{2} \mathrm{CH}_{2} \mathrm{CH}_{2} \mathrm{PPh}_{2}-\mathrm{C}, \mathrm{P}\right)\right\} \operatorname{Re}(\mathrm{CO})_{4-}$ $\mathrm{Br}(17)$. As the ring strain lessens, the spectral data for the coordinated isocyanide ligand of $\mathbf{1 7}$ exhibit the normal features; i.e. both the infrared absorption and ${ }^{13} \mathrm{C}$ NMR chemical shift of the isocyanide group are similar to those of non-chelate complexes (Table 1).
Addition of (cyclooctadiene) $\mathrm{PdCl}_{2}$ to $\mathrm{Ph}_{3} \mathrm{P}=\mathrm{N}\left(\mathrm{CH}_{2}\right)_{3}$ $\mathrm{PPh}_{2}(\mathbf{1})$ in dichloromethane resulted in formation of palladium complex 18 as a yellow solid. This compound is stable, even in the presence of moisture. Complex 18 in chloroform- $d_{1}$ solution exhibited a pair of doublets in the ${ }^{31} \mathrm{P}$ NMR spectrum at 17.2 and $40.5 \mathrm{ppm}$ with a coupling constant of $3.3 \mathrm{~Hz}$, clearly indicating that both phosphinimine and phosphine are coordinated at the metal center. The formulation of $\mathbf{1 8}$ is further confirmed with X-ray structural analysis.

The results of an X-ray structural analysis of $\mathbf{1 8}$ are depicted in Figure 2 and in Tables 3 and 4. The coordination environment about the metal center in 18 is slightly distorted square-planar with the two chloride ligands situated in a cis fashion. All bond distances and bond angles in 18 are in the normal range. The Pd$\mathrm{Cl}(1)$ bond $[2.371(2) \AA]$ is notably longer than $\mathrm{Pd}-\mathrm{Cl}(2)$ $[2.277(2) \AA]$ which is an indication of the trans influence of phosphorus versus nitrogen donors. Attempts to prepare nickel and platinum analogs of 18 were unsuccessful.

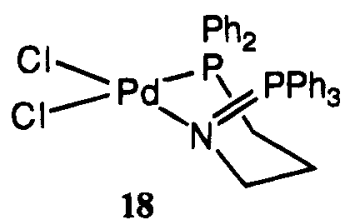

\section{Summary}

We have demonstrated various reactions of the phosphinimine-phosphine $\mathrm{Ph}_{3} \mathrm{P}=\mathrm{N}\left(\mathrm{CH}_{2}\right)_{3} \mathrm{PPh}_{2}$ (1) toward metal complexes. For coordination of phosphinimine, compound 1 acts as a $\sigma-\mathrm{P}$ donor (I), or in a $\sigma-\mathrm{N}$ and $\sigma-\mathrm{P}$ chelate fashion (II) (Chart 1). For deoxygenation of carbonyl, compound 1 becomes an isocyanide-phosphine ligand $\mathrm{CN}\left(\mathrm{CH}_{2}\right)_{3} \mathrm{PPh}_{2}$, which acts as a $\sigma$-C donor (III), a $\sigma$-C and $\sigma$-P chelate (IV), a $\sigma$-C and $\sigma$-P bridging mode with a metal-metal bond $(\mathbf{V})$, and a $\sigma-\mathrm{C}$ and $\sigma-\mathrm{P}$ bridging mode without a metal-metal bond (VI).

\section{Experimental Section}

General Information. Nuclear magnetic resonance spectra were recorded on either a Bruker AC-E 200 or a AM-300 spectrometer. For ${ }^{31} \mathrm{P}$ NMR spectra, the chemical shifts are given in parts per million $(\delta)$ relative to $85 \% \mathrm{H}_{3} \mathrm{PO}_{4}$. Infrared spectra were measured on a Biorad FT-30 instruments. The 


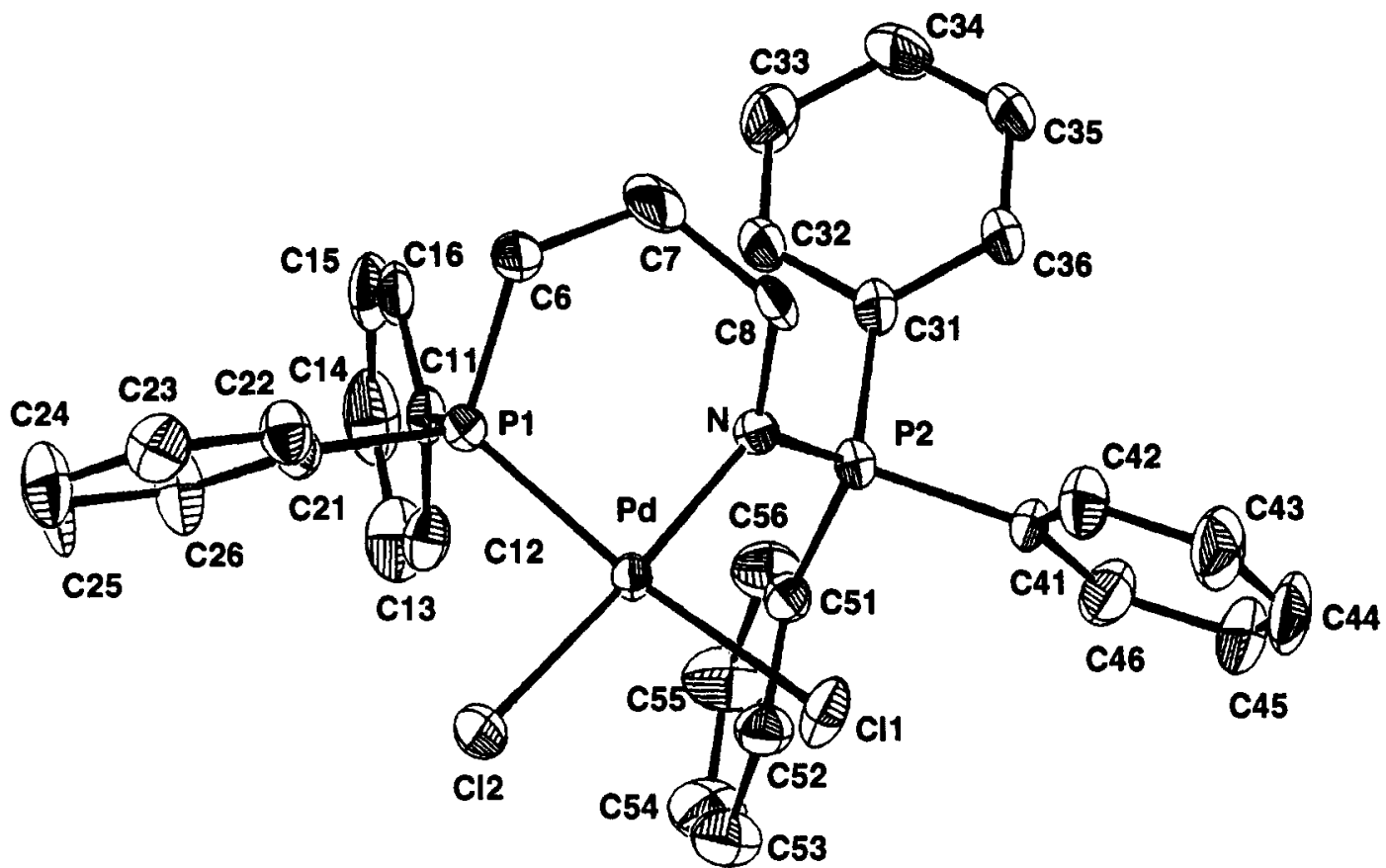

Figure 2. ORTEP diagram of palladium complex 18 showing $50 \%$ probability thermal ellipsoids.

Table 4. Atomic Coordinates and Thermal Parameters of 18

\begin{tabular}{lclcl}
\hline & $x$ & \multicolumn{1}{c}{$y$} & $z$ & $B_{\text {eq }} \AA^{2}$ \\
\hline Pd & $0.40595(5)$ & $0.76395(4)$ & $0.05976(3)$ & $2.54(3)$ \\
C11 & $0.22543(19)$ & $0.70733(15)$ & $-0.01970(10)$ & $4.61(11)$ \\
C12 & $0.52498(20)$ & $0.78297(15)$ & $-0.02029(10)$ & $4.66(11)$ \\
P1 & $0.55445(19)$ & $0.83510(14)$ & $0.13482(10)$ & $2.83(10)$ \\
P2 & $0.26680(19)$ & $0.65156(15)$ & $0.16298(10)$ & $2.98(10)$ \\
N & $0.3129(5)$ & $0.7467(4)$ & $0.13834(24)$ & $2.7(3)$ \\
C6 & $0.4730(7)$ & $0.9220(5)$ & $0.1750(4)$ & $4.2(5)$ \\
C7 & $0.3599(8)$ & $0.8910(6)$ & $0.2035(5)$ & $6.4(6)$ \\
C8 & $0.2576(7)$ & $0.8336(5)$ & $0.1581(4)$ & $4.1(4)$ \\
C12 & $0.6423(6)$ & $0.7590(5)$ & $0.1982(3)$ & $3.1(4)$ \\
C12 & $0.6773(7)$ & $0.6732(5)$ & $0.1780(4)$ & $3.8(4)$ \\
C13 & $0.7457(8)$ & $0.6116(6)$ & $0.2223(4)$ & $5.9(5)$ \\
C14 & $0.7754(8)$ & $0.6339(7)$ & $0.2878(4)$ & $6.5(6)$ \\
C15 & $0.7430(7)$ & $0.7182(6)$ & $0.3104(4)$ & $5.3(5)$ \\
C16 & $0.6774(6)$ & $0.7817(6)$ & $0.2640(4)$ & $4.1(4)$ \\
C21 & $0.6784(7)$ & $0.9023(5)$ & $0.1059(4)$ & $3.2(4)$ \\
C22 & $0.6451(7)$ & $0.9803(5)$ & $0.0694(4)$ & $4.1(4)$ \\
C23 & $0.7382(8)$ & $1.0339(6)$ & $0.0477(4)$ & $5.0(5)$ \\
C24 & $0.8623(8)$ & $1.0063(6)$ & $0.0621(5)$ & $6.2(6)$ \\
C25 & $0.8989(8)$ & $0.9304(7)$ & $0.0984(5)$ & $7.6(7)$ \\
C26 & $0.8097(7)$ & $0.8747(6)$ & $0.1205(5)$ & $5.5(5)$ \\
C31 & $0.2620(7)$ & $0.6629(5)$ & $0.2483(4)$ & $3.3(4)$ \\
C32 & $0.3749(7)$ & $0.6830(6)$ & $0.2937(4)$ & $4.1(4)$ \\
C33 & $0.3779(8)$ & $0.6959(6)$ & $0.3611(4)$ & $5.6(5)$ \\
C34 & $0.2595(8)$ & $0.6904(6)$ & $0.3828(4)$ & $6.2(6)$ \\
C35 & $0.1490(7)$ & $0.6709(6)$ & $0.3386(4)$ & $5.4(5)$ \\
C36 & $0.1471(7)$ & $0.6569(6)$ & $0.2726(4)$ & $4.2(4)$ \\
C41 & $0.1064(7)$ & $0.6102(5)$ & $0.1214(4)$ & $3.3(4)$ \\
C42 & $0.0163(7)$ & $0.6708(6)$ & $0.0862(4)$ & $5.0(5)$ \\
C43 & $-0.1067(8)$ & $0.6372(7)$ & $0.0561(5)$ & $6.6(6)$ \\
C44 & $-0.1337(8)$ & $0.5477(7)$ & $0.0619(5)$ & $7.0(6)$ \\
C45 & $-0.0493(9)$ & $0.4863(7)$ & $0.0963(5)$ & $7.1(6)$ \\
C46 & $0.0748(8)$ & $0.5175(6)$ & $0.1261(4)$ & $5.1(5)$ \\
C51 & $0.3744(7)$ & $0.5580(5)$ & $0.1530(4)$ & $3.1(4)$ \\
C52 & $0.3928(7)$ & $0.5353(5)$ & $0.0915(4)$ & $3.9(4)$ \\
C53 & $0.4628(8)$ & $0.4583(6)$ & $0.0823(4)$ & $5.3(5)$ \\
C54 & $0.5183(9)$ & $0.4064(6)$ & $0.1359(5)$ & $6.2(5)$ \\
C55 & $0.5056(9)$ & $0.4280(6)$ & $0.1981(4)$ & $6.2(6)$ \\
C56 & $0.4333(8)$ & $0.5045(6)$ & $0.2078(4)$ & $4.9(5)$
\end{tabular}

photochemical apparatus was a $450 \mathrm{~W}$ Conrad-Hanovia medium-pressure mercury lamp (Ace Glass).

All of the reaction, manipulation, and purification steps involving phosphines were performed under a dry nitrogen atmosphere. Tetrahydrofuran was distilled under nitrogen
Table 5. Crystal Data for Complexes 7a and 18

\begin{tabular}{|c|c|c|}
\hline & $7 a$ & 18 \\
\hline formula & $\mathrm{C}_{22} \mathrm{H}_{21} \mathrm{~F}_{6} \mathrm{NOP}_{2} \mathrm{Fe}$ & $\mathrm{C}_{33} \mathrm{H}_{31} \mathrm{Cl}_{2} \mathrm{NP}_{2} \mathrm{Pd}$ \\
\hline $\mathrm{fw}$ & 547.2 & 680.75 \\
\hline cryst syst & triclinic & monoclinic \\
\hline space group & & $P 2_{1} / n$ \\
\hline temp, $\mathbf{K}$ & 298 & 298 \\
\hline$a, \hat{A}$ & $9.175(13)$ & $10.460(3)$ \\
\hline$b, \AA$ & $17.514(9)$ & $14.440(5)$ \\
\hline$c, \AA$ & $14.481(25)$ & $20.558(8)$ \\
\hline$\alpha, \operatorname{deg}$ & $90.51(8)$ & \\
\hline$\beta, \operatorname{deg}$ & $92.28(12)$ & $101.99(3)$ \\
\hline$\gamma, \mathrm{deg}$ & $90.61(8)$ & \\
\hline$V, \AA^{3}$ & $2325(5)$ & $3038(2)$ \\
\hline $2 \theta$ range, deg & $18.68-26.30$ & $19.28-24.84$ \\
\hline$F(000)$ & 1112 & 1384 \\
\hline$Z$ & 4 & 4 \\
\hline$D_{\text {calcd }}, \mathrm{g} \mathrm{cm}^{-3}$ & 1.563 & 1.489 \\
\hline$\mu, \mathrm{cm}^{-1}$ & 8.440 & 9.757 \\
\hline scan width & $\omega-2 \theta$ & $\omega-2 \theta$ \\
\hline radiation & Mo $K \alpha$ & Mo K $\alpha$ \\
\hline cryst dimens, $\mathrm{mm}$ & $0.20 \times 0.30 \times 0.35$ & $0.30 \times 0.30 \times 0.35$ \\
\hline scan width & $2(1.00+0.35 \tan \theta)$ & $2(0.90+0.35 \tan \theta)$ \\
\hline transm range & $0.551,1.00$ & $0.913,1.00$ \\
\hline $2 \theta_{\max }, \mathrm{deg}$ & 45.0 & 45.0 \\
\hline no. of unique reflns & 6055 & 3962 \\
\hline no. of reflns obsd" & 1868 & 2821 \\
\hline computation & NRCSDP-VAX & NRCSDP-VAX \\
\hline soln method & heavy atom & heavy atom \\
\hline no. of params & 475 & 352 \\
\hline$R$ & 0.089 & 0.044 \\
\hline$R_{\mathrm{w}}$ & 0.084 & 0.033 \\
\hline$S$ & 2.67 & 2.51 \\
\hline
\end{tabular}

from sodium benzophenone ketyl. Benzene and toluene were distilled from sodium under nitrogen. Dichloromethane was dried by $\mathrm{CaH}_{2}$ and then distilled under nitrogen. Other chemicals and solvents were used from commercial sources without further purification.

$\boldsymbol{N}$-(3-(Diphenylphosphino)propyl)triphenylphosphinimine, 1. To a benzene solution of 3-azidopropyl chloride $(4.74 \mathrm{~g}, 39.6 \mathrm{mmol})$ was added a benzene solution of triphenylphosphine $(10.4 \mathrm{~g}, 39.6 \mathrm{mmol})$. The resulting solution was stirred for $8 \mathrm{~h}$, and the solvent was removed under reduced pressure. A white solid of (3-chloropropyl)tri- 


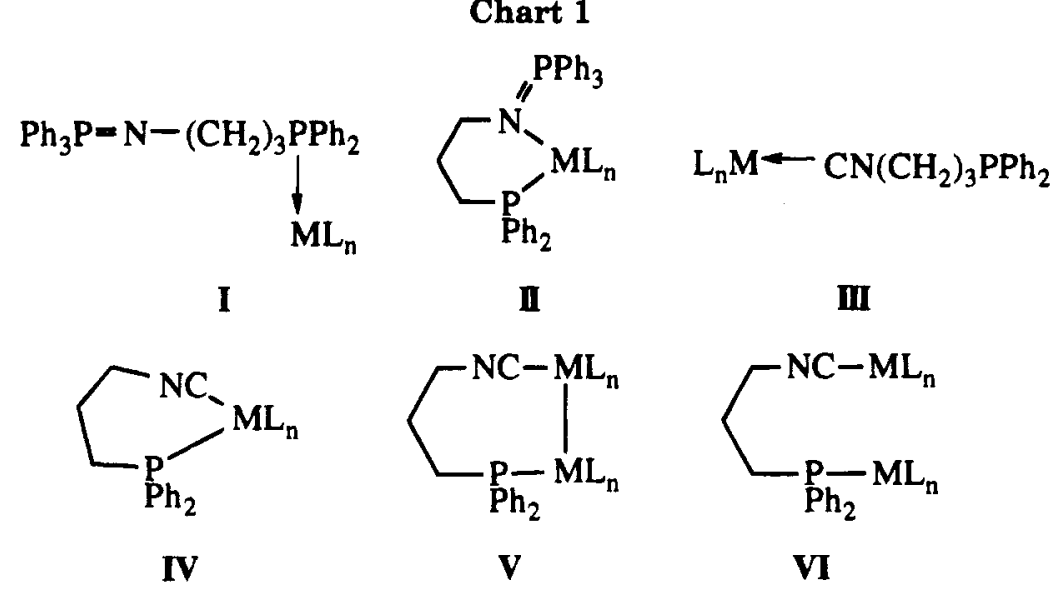

phenylphosphinimine $(15.14 \mathrm{~g}, 100 \%)$ was obtained, which was characterized by spectral methods: ${ }^{1} \mathrm{H}$ NMR $\delta 7.70-7.25(\mathrm{~m}$, $15 \mathrm{H}, \mathrm{Ar} H$ ), $3.67\left(\mathrm{t}, J=6.6 \mathrm{~Hz}, 2 \mathrm{H},-\mathrm{CH}_{2} \mathrm{Cl}\right.$ ), 3.20 (dt, $J=$ $16,6.4 \mathrm{~Hz}, 2 \mathrm{H},-\mathrm{CH}_{2} \mathrm{NP}-$ ), 1.95 (dtt, $J=1.2,6.4,6.4 \mathrm{~Hz}, 2$ $\mathrm{H},-\mathrm{CH}_{2}-$ ); ${ }^{13} \mathrm{C}$ NMR $\delta$ (aliphatic carbon) $43.6(-\mathrm{CCl}), 42.1$ $\left(\mathrm{d}, J_{\mathrm{P}-\mathrm{C}}=4.4 \mathrm{~Hz},-\mathrm{CN}=\mathrm{P}\right), 37.8\left(\mathrm{~d}, J_{\mathrm{P}-\mathrm{C}}=18.7 \mathrm{~Hz},-\mathrm{CH}_{2}-\right.$ ); ${ }^{31} \mathrm{P}$ NMR $\delta 12.4$.

A solution of diphenylphosphide anion was prepared by the addition of a $1.6 \mathrm{M}$ hexane solution of $n$-butyllithium $(25 \mathrm{~mL}$, $40 \mathrm{mmol}$ ) to a THF solution (100) $\mathrm{mL}$ ) of diphenylphosphine $(7.4 \mathrm{~g}, 39.7 \mathrm{mmol})$. This anion solution was then added to a solution of (3-chloropropyl)triphenylphosphinimine (15.4 g) in THF $(100 \mathrm{~mL})$ with stirring. The resulting mixture was kept stirred for $4 \mathrm{~h}$, and solvents were removed under reduced pressure. The residue was dissolved in benzene and filtered. The filtrate was concentrated and recrystallized from acetonitrile to give the desired compound 1 as a white solid $(13.2 \mathrm{~g}$, $66 \%$ ), which is quite sensitive to moisture: $\mathrm{mp} 120-122{ }^{\circ} \mathrm{C}$; ${ }^{1} \mathrm{H}$ NMR $\left(\mathrm{C}_{6} \mathrm{D}_{6}\right) \delta 7.80-7.50(\mathrm{~m}, 12 \mathrm{H}, \mathrm{Ar} \mathrm{H}), 7.15-6.95(\mathrm{~m}$, $13 \mathrm{H}, \operatorname{Ar} H$ ) $3.50\left(\mathrm{dt}, J=16,6.4 \mathrm{~Hz}, 2 \mathrm{H},-\mathrm{CH}_{2} \mathrm{~N}\right), 2.41(\mathrm{~m}$, $2 \mathrm{H},-\mathrm{CH}_{2} \mathrm{P}-$ ), $2.08\left(\mathrm{~m}, 2 \mathrm{H},-\mathrm{CH}_{2}-\right.$ ); ${ }^{13} \mathrm{C}$ NMR $\delta$ (aliphatic carbon) 46.8 (dd, $J=14.4,4.6 \mathrm{~Hz},-C \mathrm{NP}-$ ), 32.7 (dd, $J=20.9$, $\left.14.8 \mathrm{~Hz},-C \mathrm{PPh}_{2}\right), 26.4\left(\mathrm{~d}, J=11.5 \mathrm{~Hz},-C \mathrm{H}_{2}-\right)^{3}{ }^{31} \mathrm{P} \mathrm{NMR}$ $\left(\mathrm{C}_{6} \mathrm{D}_{6}\right) \delta 4.3,-16.0$; ${ }^{31 \mathrm{P}} \mathrm{NMR}\left(\mathrm{CDCl}_{3}\right) \delta 12.1(\mathrm{br}),-15.0$. HRMS Calcd for $\mathrm{C}_{33} \mathrm{H}_{31} \mathrm{NP}_{2}: \mathrm{m} / z$ 503.1932. Found: $\mathrm{m} / \mathrm{z}=$ 503.1933. Anal. Calcd for $\mathrm{C}_{33} \mathrm{H}_{31} \mathrm{NP}_{2}: \mathrm{C}, 78.71 ; \mathrm{H}, 6.21 ; \mathrm{N}$, 2.78. Found: C, 78.52; $\mathrm{H}, 6.26 ; \mathrm{N}, 2.75$.

$\left\{\mathbf{P h}_{2} \mathbf{P}\left(\mathrm{CH}_{2}\right)_{3} \mathrm{NPPh}_{3}-\boldsymbol{P}, \boldsymbol{N}\right\} \mathrm{Mo}(\mathrm{CO})_{4}(\mathbf{2})$, A mixture of 1 $(201 \mathrm{mg}, 0.40 \mathrm{mmol})$ and $\mathrm{Et}_{4} \mathrm{~N}\left[\mathrm{Mo}(\mathrm{CO})_{5} \mathrm{Br}\right](175 \mathrm{mg}, 0.38$ $\mathrm{mmol}$ ) in THF (10 mL) was heated to reflux for $8 \mathrm{~h}$. The reaction mixture was filtered, and the filtrate was concentrated to give the desired complex 2 as a yellow solid $(175 \mathrm{mg}, 66 \%)$; $\mathrm{mp} 125-138^{\circ} \mathrm{C} \mathrm{dec}$; IR (THF) $v_{\mathrm{CO}} 2004,1891,1875,1843 \mathrm{~cm}^{-1}$; ${ }^{1} \mathrm{H}$ NMR $\left(\mathrm{CDCl}_{3}\right) \delta 7.71-7.20(\mathrm{~m}, 25 \mathrm{H}, \mathrm{Ar} H), 3.47\left(\mathrm{dm}, J_{\mathrm{P}-\mathrm{H}}\right.$ $\left.=20.7 \mathrm{~Hz}, 2 \mathrm{H},-\mathrm{CH}_{2} \mathrm{NP}-\right), 2.62\left(\mathrm{~m}, 2 \mathrm{H},-\mathrm{CH}_{2} \mathrm{P}-\right), 1.64(\mathrm{~m}$, $2 \mathrm{H},-\mathrm{CH}_{2}-$ ); ${ }^{13} \mathrm{C}$ NMR $\delta$ (aliphatic) $54.8\left(\mathrm{~d}, J=5.1 \mathrm{~Hz},-\mathrm{CH}_{2^{-}}\right.$ $\mathrm{NP}-$ ), $29.3\left(\mathrm{~d}, J=15.1 \mathrm{~Hz},-C \mathrm{PPh}_{2}\right), 28.0(\mathrm{~d}, J=8.6 \mathrm{~Hz}$, $\left.-\mathrm{CH}_{2}-\right) ;{ }^{31} \mathrm{P}$ NMR $\delta 39.4(\mathrm{~d}, J=14 \mathrm{~Hz}), 16.3(\mathrm{~d}, J=14 \mathrm{~Hz})$. Anal. Calcd for $\mathrm{C}_{37} \mathrm{H}_{31} \mathrm{NO}_{4} \mathrm{P}_{2} \mathrm{Mo}$ : C, 62.46; $\mathrm{H}, 4.39 ; \mathrm{N}, 1.97$. Found: $\mathrm{C}, 62.00 ; \mathrm{H}, 4.80 ; \mathrm{N}, 1.86$.

$\left\{\mathbf{P h}_{2} \mathbf{P}\left(\mathbf{C H}_{2}\right)_{3} \mathbf{N P P h} \mathbf{P}_{3}-\boldsymbol{P}, \boldsymbol{N}\right\} \mathbf{W}(\mathbf{C O})_{4}$ (3). The preparation of 3 was similar to the procedure described for 2 . Complex 3 is a yellow solid: $\mathrm{mp} 179-186^{\circ} \mathrm{C} \mathrm{dec}$; IR (THF) $\nu_{\mathrm{CO}} 1998,1881$, $1863,1838 \mathrm{~cm}^{-1} ;{ }^{1} \mathrm{H}$ NMR $\left(\mathrm{CDCl}_{3}\right) \delta 7.22-7.40(\mathrm{~m}, 25 \mathrm{H}, \mathrm{Ar}$ $H$ ), $3.67\left(\mathrm{dm}, J_{\mathrm{P}-\mathrm{H}}=19.5 \mathrm{~Hz}, 2 \mathrm{H},-\mathrm{CH}_{2} \mathrm{NP}-\right.$ ), $2.77(\mathrm{~m}, 2 \mathrm{H}$, $-\mathrm{C} H_{2} \mathrm{P}-$ ), $1.67\left(\mathrm{~m}, 2 \mathrm{H},-\mathrm{CH}_{2}-\right) ;{ }^{13} \mathrm{C}$ NMR $\delta$ (aliphatic) 56.1 $(\mathrm{d}, J=5.7 \mathrm{~Hz},-C \mathrm{NP}-), 29.4\left(\mathrm{~d}, J=18.5 \mathrm{~Hz},-C \mathrm{PPh}_{2}\right), 27.8$ (d, $J=8.3 \mathrm{~Hz},-\mathrm{CH}_{2}-$ ); ${ }^{31} \mathrm{P}$ NMR $\delta 37.9(\mathrm{~d}, J=18 \mathrm{~Hz}), 2.67$ (dt, $J_{\mathrm{P}-\mathrm{P}}=18 \mathrm{~Hz}, J_{\mathrm{P}-\mathrm{W}}=224 \mathrm{~Hz}$ ). Anal. Calcd for $\mathrm{C}_{37} \mathrm{H}_{31-}$ $\mathrm{NO}_{4} \mathrm{P}_{2} \mathrm{~W}$ : C, 55.59; H, 3.91; N, 1.75. Found: C, 55.20; H, 3.90; N, 2.10 .

General Procedure for Preparation of $\mathrm{M}(\mathrm{CO})_{5}\left(\mathrm{CNCH}_{2-}\right.$ $\left.\mathrm{CH}_{2} \mathrm{CH}_{2} \mathrm{PPh}_{2}-\mathrm{C}\right)[\mathrm{M}=\mathrm{Cr}, \mathrm{Mo}, \mathrm{W}]$. A mixture of $\mathrm{M}(\mathrm{CO})_{6}$ and 1 in equimolar quantity in THF was stirred at $25^{\circ} \mathrm{C}$ for $40 \mathrm{~h}$.
The reaction mixture was concentrated, and the residue was chromatographed on silica gel with elution of dichloromethane. A yellow band was collected and concentrated to give the desired product.

$\left\{\mathbf{P h}_{2} \mathbf{P}\left(\mathbf{C H}_{2}\right)_{3} \mathbf{N C}-\mathrm{C}\right\} \mathbf{C r}(\mathbf{C O})_{5}$ (4). A yellow liquid (46\% yield): IR $\left(\mathrm{CH}_{2} \mathrm{Cl}_{2}\right) v_{\mathrm{CN}} 2173 \mathrm{~cm}^{-1}, v_{\mathrm{CO}} 2066,1955 \mathrm{~cm}^{-1} ;{ }^{1} \mathrm{H}$ NMR $\delta 7.47-7.32(\mathrm{~m}, 10 \mathrm{H}, \operatorname{Ar} H), 3.65(\mathrm{t}, J=6.4 \mathrm{~Hz}, 2 \mathrm{H}$, $\left.-\mathrm{NCH}_{2}\right), 2.18\left(\mathrm{~m}, 2 \mathrm{H},-\mathrm{CH}_{2} \mathrm{P}-\right), 1.85\left(\mathrm{~m}, 2 \mathrm{H},-\mathrm{CH}_{2}-\right) ;{ }^{13} \mathrm{C}$ NMR $\delta 216.9,214.9,162.5(C \mathrm{~N}-), 137.5(\mathrm{~d}, J=11 \mathrm{~Hz}), 132.6$ $(\mathrm{d}, J=19 \mathrm{~Hz}), 129.0,128.7(\mathrm{~d}, J=5.8 \mathrm{~Hz}), 45.3(\mathrm{~d}, J=14.3$ $\mathrm{Hz}), 26.1\left(\mathrm{~d}, J=19.3 \mathrm{~Hz},-\mathrm{CH}_{2} \mathrm{P}-\right.$ ), $25.0(\mathrm{~d}, J=12.7 \mathrm{~Hz}$, $-\mathrm{CH}_{2}-$ ); ${ }^{31} \mathrm{P}$ NMR $\delta$-17.66. Anal. Calcd for $\mathrm{C}_{21} \mathrm{H}_{16} \mathrm{NO}_{5} \mathrm{PCr}$ : C, 56.64; H, 3.62; N, 3.15. Found: C, 56.60; H, 3.10; N, 2.94.

$\left\{\mathbf{P h}_{2} \mathbf{P}\left(\mathrm{CH}_{2}\right)_{3} \mathbf{N C}-\mathrm{C}\right\} \mathbf{M o}(\mathbf{C O})_{5}(\mathbf{5})$. A yellow liquid (50\%): IR $\left(\mathrm{CH}_{2} \mathrm{Cl}_{2}\right) v_{\mathrm{CN}} 2173 \mathrm{~cm}^{-1}, v_{\mathrm{CO}} 2071,1952 \mathrm{~cm}^{-1} ;{ }^{1} \mathrm{H}$ NMR $\delta 7.51-$ $7.33(\mathrm{~m}, 10 \mathrm{H}, \mathrm{Ar} H), 3.67\left(\mathrm{t}, J=6.5 \mathrm{~Hz}, 2 \mathrm{H},-\mathrm{NCH}_{2}-\right), 2.21$ $\left(\mathrm{m}, 2 \mathrm{H},-\mathrm{CH}_{2} \mathrm{PPh}_{2}\right), 1.89\left(\mathrm{~m}, 2 \mathrm{H},-\mathrm{CH}_{2}-\right) ;{ }^{13} \mathrm{C} \mathrm{NMR} \delta 206.7$, $203.8,153.4(C \mathrm{~N}-), 137.4(\mathrm{~d}, J=12.5 \mathrm{~Hz}), 132.5(\mathrm{~d}, J=19$ $\mathrm{Hz}), 129.0,128.6(\mathrm{~d}, J=6.8 \mathrm{~Hz}), 44.8(\mathrm{~d}, J=14.3 \mathrm{~Hz}), 25.9$ $(\mathrm{d}, J=18.2 \mathrm{~Hz}), 24.9(\mathrm{~d}, J=13.7 \mathrm{~Hz}) ;{ }^{31} \mathrm{P}$ NMR $\delta-17.71$. Anal. Calcd for $\mathrm{C}_{21} \mathrm{H}_{16} \mathrm{NO}_{5} \mathrm{PMO}$ : C, 51.55; $\mathrm{H}, 3.30 ; \mathrm{N}, 2.80$. Found: C, 51.52; H, 3.40; N, 2.83.

$\left\{\mathbf{P h}_{2} \mathbf{P}\left(\mathrm{CH}_{2}\right)_{3} \mathbf{N C}-\mathrm{C}\right\} \mathbf{W}(\mathbf{C O})_{5}$ (6). A yellow liquid (67\%): IR $\left(\mathrm{CH}_{2} \mathrm{Cl}_{2}\right) v_{\mathrm{CN}} 2175 \mathrm{~cm}^{-1}, v_{\mathrm{CO}} 2068,1956 \mathrm{~cm}^{-1} ;{ }^{1} \mathrm{H}$ NMR $\delta 7.47-$ $7.32(\mathrm{~m}, 10 \mathrm{H}, \mathrm{Ar} H), 3.72\left(\mathrm{t}, J=6.5 \mathrm{~Hz}, 2 \mathrm{H},-\mathrm{NCH}_{2}\right), 2.19$ $\left(\mathrm{m}, 2 \mathrm{H},-\mathrm{CH}_{2} \mathrm{P}-\right), 1.89\left(\mathrm{~m}, 2 \mathrm{H},-\mathrm{CH}_{2}-\right) ;{ }^{13} \mathrm{C} \mathrm{NMR} \delta 196.1$, $194.3,143.0,137.4(\mathrm{~d}, J=12.3 \mathrm{~Hz}), 132.6(\mathrm{~d}, J=18.2 \mathrm{~Hz})$, $129.0,128.7(\mathrm{~d}, J=6.9 \mathrm{~Hz}), 45.0(\mathrm{~d}, J=14.2 \mathrm{~Hz}), 26.10(\mathrm{~d}, J$ $=18.3 \mathrm{~Hz}), 25.0(\mathrm{~d}, J=12.9 \mathrm{~Hz}) ;{ }^{11} \mathrm{P}$ NMR $\delta-17.75$. Anal. Calcd for $\mathrm{C}_{21} \mathrm{H}_{16} \mathrm{NO}_{5} \mathrm{PW}$ : C, 43.70; $\mathrm{H}, 2.79 ; \mathrm{N}, 2.43$. Found: C, 43.77; H, 2.76; N, 2.44.

[ $\left.\left\{\mathrm{Ph}_{2} \mathrm{P}\left(\mathrm{CH}_{2}\right)_{3} \mathrm{NC}-\mathrm{P}, \mathrm{C}\right\} \mathrm{Fe}(\mathrm{CO})\right]$ (7). A solution of $\mathrm{CpFe}-$ $(\mathrm{CO})_{2} \mathrm{I}(75.9 \mathrm{mg}, 0.25 \mathrm{mmol})$ and $1(126 \mathrm{mg}, 0.25 \mathrm{mmol})$ in toluene $(20 \mathrm{~mL})$ was stirred at room temperature for $4 \mathrm{~h}$. A yellow precipitate formed during the reaction was collected by filtration. The yellow solid was washed with toluene and hexane to give the pure complex $7(110 \mathrm{mg}, 83 \%)$ : $\mathrm{mp} 165-$ $169{ }^{\circ} \mathrm{C} \mathrm{dec}$; IR $\left(\mathrm{CHCl}_{3}\right) 2089\left(\nu_{\mathrm{CN}}\right), 1998 \mathrm{~cm}^{-1}\left(\nu_{\mathrm{Co}}\right) ;{ }^{1} \mathrm{H}$ NMR $\left(\mathrm{CDCl}_{3}\right) \delta 7.64-7.13(\mathrm{~m}, 10 \mathrm{H}), 4.97(\mathrm{~s}, 5 \mathrm{H}), 4.57-4.48(\mathrm{~m}, 1$ $\mathrm{H}), 3.67-3.56(\mathrm{~m}, 1 \mathrm{H}), 3.50-3.42(\mathrm{~m}, 1 \mathrm{H}), 2.74-2.62(\mathrm{~m}, 1$ $\mathrm{H}), 2.30-2.20(\mathrm{~m}, 1 \mathrm{H}), 2.20-2.05(\mathrm{~m}, 1 \mathrm{H}) ;{ }^{13} \mathrm{C} \mathrm{NMR}\left(\mathrm{CDCl}_{3}\right)$ $\delta 213.0(\mathrm{~d}, J=22.3 \mathrm{~Hz},-\mathrm{CO}), 183.7(\mathrm{~d}, J=35.1 \mathrm{~Hz},-\mathrm{NC}$ ), $133.9,128.1(\mathrm{~m}), 48.9,32.0(\mathrm{~d}, J=31 \mathrm{~Hz}), 28.8(\mathrm{~d}, J=4.8$ $\mathrm{Hz}) ;{ }^{31} \mathrm{P} \mathrm{NMR}\left(\mathrm{CDCl}_{3}\right) \delta 54.0 ; \mathrm{FAB} m / z=402$. Anal. Calcd for $\mathrm{C}_{22} \mathrm{H}_{21} \mathrm{INPOFe}$ : $\mathrm{C}, 49.94 ; \mathrm{H}, 4.00 ; \mathrm{N}, 2.65$. Found: $\mathrm{C}$, 49.59; H, 4.05; N, 2.53 .

$\left[\left\{\mathrm{Ph}_{2} \mathrm{P}\left(\mathrm{CH}_{2}\right)_{3} \mathrm{NC} \cdot \mathrm{P}, \mathrm{C}\right\} \mathrm{Fe}(\mathrm{CO})\right] \mathrm{PF}_{6}(\mathbf{7 a})$. A solution of 7 and excess $\mathrm{NH}_{4} \mathrm{PF}_{6}$ in acetone was stirred for $4 \mathrm{~h}$. The reaction mixture was filtered and concentrated, and the residue was recrystallized from a mixed solvent (hexane $/ \mathrm{CH}_{2} \mathrm{Cl}_{2}$ ) to give $7 \mathbf{a}$ as a yellow solid quantitatively: $\mathrm{mp} 175-180^{\circ} \mathrm{C}$ dec; IR (KBr) $2098\left(v_{\mathrm{CN}}\right), 2011 \mathrm{~cm}^{-1}\left(v_{\mathrm{CO}}\right) ;{ }^{1} \mathrm{H}$ NMR $\left(\mathrm{CDCl}_{3}\right) \delta 7.64-$ $7.13(\mathrm{~m}, 10 \mathrm{H}, \mathrm{Ar} H), 4.87(\mathrm{~s}, 5 \mathrm{H}, \mathrm{Cp} H), 4.03(\mathrm{~m}, 1 \mathrm{H}), 3.50$ 
$(\mathrm{m}, 1 \mathrm{H}), 2.96(\mathrm{~m}, 1 \mathrm{H}), 2.60(\mathrm{~m}, 1 \mathrm{H}), 2.20(\mathrm{~m}, 1 \mathrm{H}), 2.00(\mathrm{~m}$, $1 \mathrm{H}) ;{ }^{31} \mathrm{P} \mathrm{NMR}\left(\mathrm{CDCl}_{3}\right) \delta 54.0,-143.6\left(\mathrm{PF}_{6}\right)$.

$\left[\left\{\mathbf{P h}_{2} \mathbf{P}\left(\mathrm{CH}_{2}\right)_{3} \mathbf{N H}(n-\mathrm{PrNH}) \mathrm{C}=\right\} \mathbf{F e}(\mathrm{CO})\right] \mathbf{I}(8)$. A mixture of $n$-propylamine $(5 \mathrm{~mL})$ and $7(450 \mathrm{mg}, 0.166 \mathrm{mmol})$ in dichloromethane $(20 \mathrm{~mL})$ was stirred at $25^{\circ} \mathrm{C}$ for $1 \mathrm{~h}$. On removal of the solvent, the residue was crystallized from chloroform and pentane to give $\mathbf{8}$ as a yellow crystalline solid (435 mg, 87\%): $\mathrm{mp} 185-190^{\circ} \mathrm{C}$ dec; IR $\left(\mathrm{CH}_{2} \mathrm{Cl}_{2}\right) v(\mathrm{CO}) 1949$ $\mathrm{cm}^{-1} ;{ }^{1} \mathrm{H}$ NMR $\left(\mathrm{CDCl}_{3}\right) \delta 8.31(\mathrm{br}, 1 \mathrm{H}), 7.49-7.12(\mathrm{~m}, 10 \mathrm{H})$, $6.40(\mathrm{br}, 1 \mathrm{H}), 4.53(\mathrm{~s}, 5 \mathrm{H}), 4.35(\mathrm{~m}, 1 \mathrm{H}), 3.60(\mathrm{~m}, 2 \mathrm{H}), 3.50$ $(\mathrm{m}, 1 \mathrm{H}), 2.79(\mathrm{~m}, 2 \mathrm{H}), 2.17(\mathrm{~m}, 1 \mathrm{H}), 2.11(\mathrm{~m}, 2 \mathrm{H}), 1.30(\mathrm{~m}$, $1 \mathrm{H}), 1.11(\mathrm{t}, J=7 \mathrm{~Hz}, 3 \mathrm{H}) ;{ }^{13} \mathrm{C} \mathrm{NMR}\left(\mathrm{CDCl}_{3}\right) \delta 218.6(\mathrm{~d}, J=$ $31.8 \mathrm{~Hz}$ ), $209.8(\mathrm{~d}, J=25.6 \mathrm{~Hz}), 139.2(\mathrm{~d}, J=48.3 \mathrm{~Hz}), 132.9$ $(\mathrm{d}, J=47 \mathrm{~Hz}), 132.8(\mathrm{~d}, J=9.4 \mathrm{~Hz}), 131.02(\mathrm{~d}, J=1.9 \mathrm{~Hz})$, $130.2(\mathrm{~d}, J=1.7 \mathrm{~Hz}), 130.0$ (d, $J=8.6 \mathrm{~Hz}), 129.0$ (d, $J=9.5$ $\mathrm{Hz}), 128.6(\mathrm{~d}, J=9.8 \mathrm{~Hz}), 84.7,48.2,45.5,35.5(\mathrm{~d}, J=22$ $\mathrm{Hz}), 24.8,21.9,11.6 ;{ }^{31} \mathrm{P} \mathrm{NMR}\left(\mathrm{CDCl}_{3}\right) \delta 56.5$. Anal. Calcd for $\mathrm{C}_{25} \mathrm{H}_{30} \mathrm{IN}_{2} \mathrm{POFe}$ : C, $51.05 ; \mathrm{H}, 5.14 ; \mathrm{N}, 4.76$. Found: $\mathrm{C}$, $52.12 ; \mathrm{H}, 5.07 ; \mathrm{N}, 4.84$.

[CpRu $\left.\left\{\mathrm{Ph}_{2} \mathbf{P}\left(\mathrm{CH}_{2}\right)_{3} \mathrm{NPPh}_{3}-\mathbf{P}\right\}\left(\mathrm{PPh}_{3}\right) \mathrm{Cl}\right](\mathbf{9})$. A mixture of $\mathrm{CpRu}\left(\mathrm{PPh}_{3}\right)_{2} \mathrm{Cl}(634 \mathrm{mg}, 0.873 \mathrm{mmol})$ and 1 (440 mg, 0.873 mmol) in benzene ( $40 \mathrm{~mL}$ ) was heated to reflux for $4 \mathrm{~h}$. The benzene solvent was replaced by ether, and a yellow precipitate was formed and collected. The precipitate was subsequently washed with ether $(20 \mathrm{~mL} \times 2)$ to give complex 5 as a yellow solid (570 mg, 68\%): $\mathrm{mp} 122-125{ }^{\circ} \mathrm{C} \mathrm{dec} ;{ }^{1} \mathrm{H} \mathrm{NMR}\left(\mathrm{CDCl}_{3}\right) \delta$ $7.80-6.95(\mathrm{~m}, 40 \mathrm{H}), 4.03(\mathrm{~s}, 5 \mathrm{H}), 2.61(\mathrm{dt}, J=20,7.8 \mathrm{~Hz}, 2$ $\mathrm{H}), 2.21-2.11(\mathrm{~m}, 1 \mathrm{H}), 1.38-1.20(\mathrm{~m}, 1 \mathrm{H}), 0.80-0.60(\mathrm{~m}, 2$ $\mathrm{H}) ;{ }^{13} \mathrm{C}$ NMR $\delta$ (aliphatic) $80.5,43.0(\mathrm{~d}, J=11.6 \mathrm{~Hz}), 28.4(\mathrm{~d}$, $J=8.9 \mathrm{~Hz}), 18.9(\mathrm{dd}, J=38.7,20 \mathrm{~Hz}) ;{ }^{31} \mathrm{P}$ NMR $\delta 44.1(\mathrm{~d}, J$ $=41.4 \mathrm{~Hz}), 36.8(\mathrm{~d}, J=41.4 \mathrm{~Hz}), 13.0(\mathrm{br}) ; \mathrm{FAB}(m+1) / z=$ 968. Anal. Calcd for $\mathrm{C}_{56} \mathrm{H}_{51} \mathrm{NP}_{3} \mathrm{RuCl}$ : C, 69.52; H, 5.31; N, 1.45. Found: C, $69.31 ; \mathrm{H}, 5.24 ; \mathrm{N}, 1.57$.

[CpRu $\left\{\mathrm{Ph}_{2} \mathrm{P}\left(\mathrm{CH}_{2}\right)\right.$ NC-C $\left.\}(\mathrm{CO}) \mathrm{I}\right]$ (10). To a solution of $\mathrm{CpRu}(\mathrm{CO})_{2} \mathrm{I}(200 \mathrm{mg}, 0.57 \mathrm{mmol})$ in dichloromethane was added compound 1 ( $302 \mathrm{mg}, 0.60 \mathrm{mmol}$ ); the resulting mixture was stirred at room temperature for $10 \mathrm{~h}$. Removal of solvent yielded a liquid residue, which was chromatographed on alumina ( $10 \mathrm{~g})$ with elution with dichloromethane. A red band eluate was collected and concentrated to give the complex 6 as a red liquid $(272 \mathrm{mg}, 83 \%)$ : IR $\left(\mathrm{CH}_{2} \mathrm{Cl}_{2}\right) \nu(-\mathrm{NC}) 2170, v$ (-CO) $1973 \mathrm{~cm}^{-1} ;{ }^{1} \mathrm{H}$ NMR $87.46-7.24(\mathrm{~m}, 10 \mathrm{H}), 5.14(\mathrm{~s}, 5$ $\mathrm{H}), 3.82(\mathrm{t}, J=6.4 \mathrm{~Hz}, 2 \mathrm{H}), 2.25-2.19(\mathrm{~m}, 2 \mathrm{H}), 1.92-1.79$ $(\mathrm{m}, 2 \mathrm{H}) ;{ }^{13} \mathrm{C}$ NMR $\delta 199.5(-\mathrm{CO}), 145.1(\mathrm{CN}-), 137.5-128.6$ (Ar C), $84.4(\mathrm{Cp}-), 45.7$ (d, $J=14.5 \mathrm{~Hz}), 26.3$ (d, $J=18.1$ $\mathrm{Hz}), 24.8(\mathrm{~d}, J=11.9 \mathrm{~Hz}) ;{ }^{31} \mathrm{P}$ NMR $\delta-17.3$. Anal. Calcd for $\mathrm{C}_{22} \mathrm{H}_{21}$ INOPRu: $\mathrm{C}, 46.01 ; \mathrm{H}, 3.69 ; \mathrm{N}, 2.44$. Found: $\mathrm{C}, 45.78$; $\mathrm{H}, 3.69 ; \mathrm{N}, 2.46$.

$\left[\mathrm{Cp}\left(\mathrm{PPh}_{3}\right) \mathrm{ClRu}\left\{\mu-\mathrm{Ph}_{2} \mathrm{P}\left(\mathrm{CH}_{2}\right)_{3} \mathrm{NC}-\mathrm{P}, C\right\} \mathrm{RuCp}(\mathrm{CO}) \mathrm{I}\right]$ (11).

Method 1. A mixture of 9 (140 mg, $0.144 \mathrm{mmol})$ and $\mathrm{CpRu}-$ $(\mathrm{CO})_{2} \mathrm{I}(50.4 \mathrm{mg}, 0.144 \mathrm{mmol})$ in toluene $(10 \mathrm{~mL})$ was stirred at room temperature for $10 \mathrm{~h}$. Concentration of the reaction mixture gave the crude product as a red solid, which was purified by chromatography on alumina with elution of dichloromethane. Recrystallization from $\mathrm{CHCl}_{3}$ /pentane at $-20^{\circ} \mathrm{C}$ provided the desired complex 11 as an orange crystalline solid (107 mg, 72\%).

Method 2. A benzene solution of $10(60 \mathrm{mg}, 0.104 \mathrm{mmol})$ and $\mathrm{CpRu}\left(\mathrm{PPh}_{3}\right)_{2} \mathrm{Cl}(75.8 \mathrm{mg}, 0.104 \mathrm{mmol})$ was heated to reflux for $4 \mathrm{~h}$. Replacement of benzene with ether solvent yielded a red precipitate solid, which was washed with ether $(20 \mathrm{~mL}$, $\times 2)$ to provide pure 11 as an orange-red solid (63 $\mathrm{mg}, 58 \%$ ).

Both methods provided formation of diastereomeric pairs of 11, which could not be separated at present. IR $\left(\mathrm{CH}_{2} \mathrm{Cl}_{2}\right)$ : $v(-\mathrm{NC}) 2170, v(-\mathrm{CO}) 1970 \mathrm{~cm}^{-1}$. ${ }^{1} \mathrm{H}$ NMR: $\delta 7.90-7.88(\mathrm{~m}$, $2 \mathrm{H}), 7.50-7.04(\mathrm{~m}, 23 \mathrm{H}), 5.14(\mathrm{~s}, 5 \mathrm{H}), 4.13(\mathrm{~s}, 5 \mathrm{H}), 3.31-$ $3.13(\mathrm{~m}, 2 \mathrm{H}), 2.31-2.22(\mathrm{~m}, 1 \mathrm{H}), 1.29-1.21(\mathrm{~m}, 1 \mathrm{H}), 1.10-$ $1.00(\mathrm{~m}, 1 \mathrm{H}), 0.88-0.74(\mathrm{~m}, 1 \mathrm{H}) .{ }^{31} \mathrm{P}$ NMR: $\delta 44.12(\mathrm{~d}, J=$ $41.4 \mathrm{~Hz}), 35.74(\mathrm{~d}, J=41.4 \mathrm{~Hz})$ as one pair of diastereomers; $\delta 44.05(\mathrm{~d}, J=41.4 \mathrm{~Hz}), 35.78(\mathrm{~d}, J=41.4 \mathrm{~Hz})$. Anal. Calcd for $\mathrm{C}_{45} \mathrm{H}_{41} \mathrm{ClINOP}_{2} \mathrm{Ru}_{2} \cdot 0.5 \mathrm{CHCl}_{3}: \mathrm{C}, 49.77 ; \mathrm{H}, 3.81 ; \mathrm{N}, 1.24$. Found: C, 49.28; H, 3.74; N, 1.24 .
$\mathrm{Br}(\mathrm{CO})_{4} \mathrm{Re}\left(\mathrm{CNCH}_{2} \mathrm{CH}_{2} \mathrm{PPh}_{2}-\mathrm{C}\right)$ (12). A mixture of $\operatorname{Re}(\mathrm{CO})_{5} \operatorname{Br}(73 \mathrm{mg}, 0.18 \mathrm{mmol})$ and $1(90.5 \mathrm{mg}, 0.18 \mathrm{mmol})$ in $\mathrm{CH}_{2} \mathrm{Cl}_{2}(10 \mathrm{~mL})$ was heated to reflux for $2 \mathrm{~h}$. Ather removal of solvent, the residue was chromatographed on silica gel with dichloromethane as the eluent. The eluate was collected and concentrated to give the desired complex 12 as a colorless liquid $(75 \mathrm{mg}, 66 \%)$ : IR $\left(\mathrm{CH}_{2} \mathrm{Cl}_{2}\right) v_{\mathrm{CN}} 2222 \mathrm{~cm}^{-1}, v_{\mathrm{CO}} 2112$, $2020,1958 \mathrm{~cm}^{-1} ;{ }^{1} \mathrm{H}$ NMR $\delta 7.47-7.30(\mathrm{~m}, 10 \mathrm{H}, \operatorname{Ar} H), 3.87$ $\left(\mathrm{t}, J=6.5 \mathrm{~Hz}, 2 \mathrm{H},-\mathrm{NCH}_{2}-\right), 2.22\left(\mathrm{~m}, 2 \mathrm{H},-\mathrm{PCH}_{2}-\right), 1.93$ (m, $2 \mathrm{H},-\mathrm{CH}_{2}-$ ); ${ }^{13} \mathrm{C}$ NMR $\delta 182.3,181.1,180.1$ (-CO), 137.2 $(\mathrm{d}, J=11.2 \mathrm{~Hz}), 132.6(\mathrm{~d}, J=19.2 \mathrm{~Hz}), 129.0,128.6(\mathrm{~d}, J=$ $6.8 \mathrm{~Hz}$ ) (Ar C), $129.2(-\mathrm{CN}), 45.4\left(\mathrm{~d}, J=15.1 \mathrm{~Hz},-\mathrm{NCH}_{2}-\right.$ ), $25.6\left(\mathrm{~d}, J=18.7 \mathrm{~Hz},-\mathrm{PCH}_{2}-\right), 24.7\left(\mathrm{~d}, J=13.2,-\mathrm{CH}_{2}-\right.$ ); ${ }^{31} \mathrm{P}$ NMR $\delta-17.83$. Anal. Calcd for $\mathrm{C}_{20} \mathrm{H}_{16} \mathrm{BrNPO}_{4} \mathrm{Re}$ : C, 38.04; H, 2.22; N, 2.55. Found: C, 37.95; H, 2.31; N, 2.52.

$\mathrm{Br}(\mathrm{CO})_{3} \mathrm{Re}\left(\mathrm{CNCH}_{2} \mathrm{CH}_{2} \mathrm{CH}_{2} \mathrm{PPh}_{2}-\mathrm{P}, \mathrm{C}\right)(13)$. A solution of $12(50 \mathrm{mg}, 0.08 \mathrm{mmol})$ in benzene $(10 \mathrm{~mL})$ was heated to reflux for $4 \mathrm{~h}$. The reaction mixture was chromatographed on silica gel $(5 \mathrm{~g})$ with elution with $\mathrm{CH}_{2} \mathrm{Cl}_{2}$. The eluate was collected and concentrated to give 13 as a clear colorless liquid (35 mg, 73\%): IR $v_{\mathrm{CN}} 2137 \mathrm{~cm}^{-1}, v_{\mathrm{CO}} 2039,1975,1917 \mathrm{~cm}^{-1}$; ${ }^{1} \mathrm{H}$ NMR $\delta 7.68-7.36(\mathrm{~m}, 10 \mathrm{H}), 4.00(\mathrm{~m}, 1 \mathrm{H}), 3.44(\mathrm{~m}, 2 \mathrm{H})$, $2.76(\mathrm{~m}, 1 \mathrm{H}), 2.07(\mathrm{~m}, 2 \mathrm{H}) ;{ }^{13} \mathrm{C}$ NMR $\delta 190.2(\mathrm{~d}, J=8.9 \mathrm{~Hz})$, $187.83(\mathrm{~d}, J=58.5 \mathrm{~Hz}), 187.78(\mathrm{~d}, J=6.2 \mathrm{~Hz})(-\mathrm{CO}), 163.0$ $(\mathrm{d}, J=6.8 \mathrm{~Hz},-C \mathrm{~N}), 134.3-128.0(\operatorname{Ar} C), 47.2,28.7(\mathrm{~d}, J=$ $2.7 \mathrm{~Hz}$ ), 27.7 (d, $J=28 \mathrm{~Hz}$ ); ${ }^{31} \mathrm{P}$ NMR $\delta-4.33$. Anal. Calcd for $\mathrm{C}_{19} \mathrm{H}_{16} \mathrm{NPO}_{3} \mathrm{ReBr}: \mathrm{C}, 37.82 ; \mathrm{H}, 2.67 ; \mathrm{N}, 2.32$. Found: C, $37.57 ; \mathrm{H}, 2.73 ; \mathrm{N}, 2.30$.

(CO) $)_{3} \mathrm{BrRe}\left(\mathrm{CNCH}_{2} \mathrm{CH}_{2} \mathrm{CH}_{2} \mathrm{PPh}_{2}-\mathrm{C}\right)_{2}$ (14). A mixture of $1(920 \mathrm{mg}, 1.827 \mathrm{mmol})$ and $\operatorname{BrRe}(\mathrm{CO})_{5}(370 \mathrm{mg}, 0.911 \mathrm{mmol})$ in benzene $(40 \mathrm{~mL})$ was stirred at $25^{\circ} \mathrm{C}$ for $10 \mathrm{~h}$. After concentration of the reaction mixture, the residue was chromatographed on silica gel with dichloromethane as the eluent. The eluate was concentrated to give 14 as a colorless liquid $(565 \mathrm{mg} \mathrm{73 \%})$ : IR $\left(\mathrm{CHCl}_{3}\right) 2219\left(v_{\mathrm{CN}}\right), 2041,1981,1926 \mathrm{~cm}^{-1}$ $\left(\nu_{\mathrm{CO}}\right):{ }^{1} \mathrm{H}$ NMR $\delta 7.47-7.31(\mathrm{~m}, 20 \mathrm{H}$, Ar $H), 3.68(\mathrm{t}, J=6.4$ $\left.\mathrm{Hz}, 4 \mathrm{H}, \mathrm{CNCH}_{2}-\right), 2.17\left(\mathrm{~m}, 4 \mathrm{H},-\mathrm{CH}_{2} \mathrm{PPh}_{2}\right), 1.83(\mathrm{~m}, 4 \mathrm{H}$, $\left.-\mathrm{CH}_{2}-\right) ;{ }^{13} \mathrm{C}$ NMR $\delta 186.1,183.8,137.1(\mathrm{~d}, J=8.6 \mathrm{~Hz}), 137.0$ $(\mathrm{d}, J=8.9 \mathrm{~Hz}), 134.3(-C \mathrm{~N}), 132.4(\mathrm{~d}, J=6.8 \mathrm{~Hz}), 132.2(\mathrm{~d}$, $J=6.6 \mathrm{~Hz}), 128.7,128.6,128.3(\mathrm{~d}, J=6.6 \mathrm{~Hz}), 44.6(\mathrm{~d}, J=$ $14.5 \mathrm{~Hz}), 25.3(\mathrm{~d}, J=18.5 \mathrm{~Hz}), 24.2(\mathrm{~d}, J=13.1 \mathrm{~Hz}) ;{ }^{31} \mathrm{P}$ NMR $\delta-17.80 ;$ FABMS $(m+1) / z=857.0$. Anal. Calcd for $\mathrm{C}_{35} \mathrm{H}_{32} \mathrm{~N}_{2} \mathrm{P}_{2} \mathrm{O}_{3}$ ReBr: C, 49.07; H, 3.76; N, 3.27. Found: C, $49.01 ; \mathrm{H}, 3.80 ; \mathrm{N}, 3.26$.

$(\mathrm{CO})_{9} \mathrm{Re}_{2}\left(\mathrm{CNCH}_{2} \mathrm{CH}_{2} \mathrm{CH}_{2} \mathrm{PPh}_{2}-\mathrm{C}\right)$ (15). A solution of 1 (42 $\mathrm{mg}, 0.083 \mathrm{mmol})$ and $\mathrm{Re}_{2}(\mathrm{CO})_{10}(54 \mathrm{mg}, 0.083 \mathrm{mmol})$ in toluene $(10 \mathrm{~mL})$ was stirred at $25^{\circ} \mathrm{C}$ for $10 \mathrm{~h}$. The reaction mixture was chromatographed on silica gel with dichloromethane as the eluent. Upon concentration of the eluate, the desired product was obtained as a colorless liquid $(67 \mathrm{mg}$, 92\%): IR $2187\left(v_{\mathrm{CN}}\right), 2099,2074,2046,2008,1994,1968,1942$ $\mathrm{cm}^{-1}\left(v_{\mathrm{CO}}\right) ;{ }^{1} \mathrm{H}$ NMR $\delta 7.50-7.33(\mathrm{~m}, 10 \mathrm{H}), 3.85(\mathrm{t}, J=6.7$ $\mathrm{Hz}, 2 \mathrm{H}), 2.12(\mathrm{~m}, 2 \mathrm{H}), 1.85(\mathrm{~m}, 2 \mathrm{H}) ;{ }^{13} \mathrm{C} \mathrm{NMR} \delta 194.6,192.0$, $184.6(-\mathrm{CO}), 134.5(-\mathrm{CN}), 137.3(\mathrm{~d}, J=12 \mathrm{~Hz}), 132.6(\mathrm{~d}, J=$ $19.3 \mathrm{~Hz}), 129.0128 .7(\mathrm{~d}, J=7.6 \mathrm{~Hz})(\operatorname{Ar} C), 45.6(\mathrm{~d}, J=14.4$ $\mathrm{Hz}), 25.8(\mathrm{~d}, J=19.5 \mathrm{~Hz}), 25.0(\mathrm{~d}, J=13.9 \mathrm{~Hz}) ;{ }^{31 \mathrm{P}} \mathrm{NMR} \delta$ -17.5. Anal. Calcd for $\mathrm{C}_{25} \mathrm{H}_{16} \mathrm{NO}_{9} \mathrm{Re}_{2}$ : C, 34.21; $\mathrm{H}, 1.84 ; \mathrm{N}$, 1.60. Found: C, $34.32 ; \mathrm{H}, 1.80 ; \mathrm{N}, 1.59$.

$(\mathrm{CO})_{4} \mathrm{Re}\left\{\mu_{2}-\mathrm{CNCH}_{2} \mathrm{CH}_{2} \mathrm{CH}_{2} \mathrm{PPH}_{2}-P, C\right\} \operatorname{Re}(\mathrm{CO})_{4}$ (16). A solution of $15(640 \mathrm{mg}, 0.729 \mathrm{mmol})$ in chloform was irradiated with light for $2 \mathrm{~h}$. After concentration, the residue was chromatographed on silica gel with dichloromethane as eluent. The eluate was concentrated to give the desired product 16 as a white solid $(450 \mathrm{mg}, 73 \%): \mathrm{mp} 165-185^{\circ} \mathrm{C} \mathrm{dec}$; IR (KBr) $v 2156(-\mathrm{CN}), 2081,2062,2034,1973,1958 \mathrm{~cm}^{-1}(-\mathrm{CO}) ;{ }^{1} \mathrm{H}$ NMR $\delta 7.64-7.47(\mathrm{~m}, 10 \mathrm{H}), 3.86(\mathrm{t}, J=6 \mathrm{~Hz}, 2 \mathrm{H}), 2.92(\mathrm{~m}$, $2 \mathrm{H}), 1.83(\mathrm{~m}, 2 \mathrm{H}) ;{ }^{13} \mathrm{C}$ NMR $\delta 185.4(\mathrm{~d}, J=9 \mathrm{~Hz}), 183.5$, $183.3(\mathrm{~d}, J=7 \mathrm{~Hz}), 182.8,182.1,180.6,178.9(\mathrm{CN}-), 132.3$, $132.2(\mathrm{~d}, J=10.5 \mathrm{~Hz}), 131.5(\mathrm{~d}, J=2 \mathrm{~Hz}), 129.4(\mathrm{~d}, J=9.7$ $\mathrm{Hz}), 45.2(\mathrm{~d}, J=17 \mathrm{~Hz}), 23.5,22.9\left(\mathrm{~d}, J=30 \mathrm{~Hz}\right.$ ); ${ }^{31} \mathrm{P}$ NMR $\delta$ -0.3. Anal. Calcd for $\mathrm{C}_{24} \mathrm{H}_{16} \mathrm{NO}_{8} \mathrm{Re}_{2}: \mathrm{C}, 35.21 ; \mathrm{H}, 1.97 ; \mathrm{N}$, 1.71. Found: C, $34.93 ; \mathrm{H}, 2.05 ; \mathrm{N}, 1.69$. 
$\mathrm{Br}(\mathrm{CO})_{4} \mathrm{Re}\left\{\mu_{2}-\mathrm{CNCH}_{2} \mathrm{CH}_{2} \mathrm{CH}_{2} \mathrm{PPh}_{2}-\mathrm{P}, \mathrm{C}\right\} \mathrm{Re}(\mathrm{CO})_{4} \mathrm{Br}(17)$. Bromine ( $31 \mathrm{mg}, 0.194 \mathrm{mmol}$ ) was added to a solution of 16 $(140 \mathrm{mg}, 0.166 \mathrm{mmol})$ in dichloromethane $(100 \mathrm{~mL})$ at room temperature. After stirring for $3 \mathrm{~h}$, the reaction mixture was concentrated and the residue was chromatographed on silica gel with ethyl acetate and hexane $(1 / 4)$ as the eluent. The eluate was collected and concentrated to give $\mathbf{1 7}$ as a clear, colorless liquid (125 mg, 75\%): IR $\left(\mathrm{CH}_{2} \mathrm{Cl}_{2}\right) 2221 \mathrm{~cm}^{-1}(-\mathrm{CN})$, $2110,2021,1954 \mathrm{~cm}^{-1}(-\mathrm{CO}) ;{ }^{1} \mathrm{H}$ NMR $\delta 7.62-7.47(\mathrm{~m}, 10$ $\mathrm{H}), 3.88(\mathrm{t}, J=6 \mathrm{~Hz}, 2 \mathrm{H}), 3.02(\mathrm{~m}, 2 \mathrm{H}), 1.80(\mathrm{~m}, 2 \mathrm{H}) ;{ }^{13} \mathrm{C}$ NMR $\delta 184.2(\mathrm{~d}, J=9.2 \mathrm{~Hz}), 182.5(\mathrm{~d}, J=6.6 \mathrm{~Hz}), 182.3$, $181.7,181.0,179.9,132.0$ (d, $J=10.6 \mathrm{~Hz}$ ), 131.4, 131.3, 130.7, $129.1(\mathrm{~d}, J=9.8 \mathrm{~Hz}), 44.8(\mathrm{~d}, J=17 \mathrm{~Hz}), 24.1(\mathrm{~d}, J=31.3$ $\mathrm{Hz}), 23.2$; ${ }^{11} \mathrm{P}$ NMR $\delta-5.12$. Anal. Calcd for $\mathrm{C}_{24} \mathrm{H}_{16} \mathrm{Br}_{2} \mathrm{NO}_{8-}$ $\mathrm{Re}_{2}$ : C, 29.46; H, 1.65; N, 1.43. Found: C, 29.31; H, 1.75; N, 1.42 .

$\mathrm{Cl}_{2} \mathrm{Pd}\left(\mathrm{Ph}_{2} \mathrm{PCH}_{2} \mathrm{CH}_{2} \mathrm{CH}_{2} \mathrm{NPPh}_{3}-\boldsymbol{P}, \boldsymbol{N}\right)$ (18). A mixture of 1 (106 mg, $0.21 \mathrm{mmol})$ and $\mathrm{Pd}(\mathrm{COD}) \mathrm{Cl}_{2}(60 \mathrm{mg}, 0.21 \mathrm{mmol})$ in dichloromethane $(15 \mathrm{~mL})$ was stirred at $25{ }^{\circ} \mathrm{C}$ for $8 \mathrm{~h}$. On removal of solvents, the residue was dissolved in chloroform and pentane and the desired complex 18 crystallized as a yellow-orange solid (136 mg, 95\%): $\mathrm{mp} 154-158{ }^{\circ} \mathrm{C} \mathrm{dec} ;{ }^{1} \mathrm{H}$ NMR $\delta 7.67-7.33(\mathrm{~m}, 25 \mathrm{H}), 3.21(\mathrm{~m}, 2 \mathrm{H}), 2.05(\mathrm{~m}, 2 \mathrm{H}), 1.86$ $(\mathrm{m}, 2 \mathrm{H}) ;{ }^{13} \mathrm{C}$ NMR $\delta$ (aliphatic) $45.5(\mathrm{~d}, J=2.9 \mathrm{~Hz}), 25.3(\mathrm{~d}$, $J=9.5 \mathrm{~Hz}), 22.5(\mathrm{~d}, J=33.5 \mathrm{~Hz}) ;{ }^{31} \mathrm{P}$ NMR $\delta 40.5(\mathrm{~d}, J=3.3$
$\mathrm{Hz}$ ), 17.2 (d, $J=3.3 \mathrm{~Hz}$ ). Anal. Calcd for $\mathrm{C}_{33} \mathrm{H}_{31} \mathrm{Cl}_{2} \mathrm{NP}_{2} \mathrm{Pd}$ : C, 58.21; H, 4.59; N, 2.06. Found: C, 58.19; H, 4.84; N, 1.81 .

X-ray Crystallography. Single crystals suitable for X-ray analysis of complexes $\mathbf{7 a}$ and $\mathbf{1 8}$ were obtained in each case by slow evaporation of a chloroform/pentane solution under air. Cell parameters were determined on a CAD-4 diffractometer at $298 \mathrm{~K}$ by a least-squares treatment. Atomic scattering factors were taken from ref 24 . The NRCC SDP VAX program was used for calculation. ${ }^{25}$ Crystal data of these complexes are summarized in Table 5, and their non-hydrogen atomic coordinates are listed in Tables 2 and 4, respectively.

Acknowledgment. We thank the National Science Council of the Republic of Chinafor grant support (NSC84-2113-M002-018).

Supplementary Material Available: Anisotropic thermal parameters and complete bond distances and bond angles for $7 a$ and 18 (7 pages). Ordering information is given on any current masthead page.

\section{OM940875K}

(24) International Tables for X-ray Crystallography; Kynoch Press: Birmingham, U.K., 1974; Vol. IV.

(25) Gabe, E. J.; Lee, F. L. Acta Crystallogr. 1981, A37, S339. 